\title{
Chlorella vulgaris Modulates Genes and Muscle-Specific microRNAs Expression to Promote Myoblast Differentiation in Culture
}

\author{
Nurhazirah Zainul Azlan $\mathbb{D D}^{1,2}$ Yasmin Anum Mohd Yusof ${ }^{10},^{1}$ \\ Ekram Alias, ${ }^{1}$ and Suzana Makpol ${ }^{1}{ }^{1}$ \\ ${ }^{1}$ Department of Biochemistry, Faculty of Medicine, Level 17, Preclinical Building, Universiti Kebangsaan Malaysia Medical Centre, \\ Jalan Yaacob Latif, Bandar Tun Razak, Cheras, 56000 Kuala Lumpur, Malaysia \\ ${ }^{2}$ Department of Basic Medical Sciences for Nursing, Kulliyyah of Nursing, International Islamic University Malaysia, \\ P.O. Box 141, 25710 Kuantan, Pahang, Malaysia \\ Correspondence should be addressed to Suzana Makpol; suzanamakpol@ppukm.ukm.edu.my
}

Received 20 April 2019; Revised 12 June 2019; Accepted 3 July 2019; Published 21 July 2019

Academic Editor: Carmen Mannucci

Copyright (C) 2019 Nurhazirah Zainul Azlan et al. This is an open access article distributed under the Creative Commons Attribution License, which permits unrestricted use, distribution, and reproduction in any medium, provided the original work is properly cited.

Background. Loss of skeletal muscle mass, strength, and function due to gradual decline in the regeneration of skeletal muscle fibers was observed with advancing age. This condition is known as sarcopenia. Myogenic regulatory factors (MRFs) are essential in muscle regeneration as its activation leads to the differentiation of myoblasts to myofibers. Chlorella vulgaris is a coccoid green eukaryotic microalga that contains highly nutritious substances and has been reported for its pharmaceutical effects. The aim of this study was to determine the effect of $C$. vulgaris on the regulation of MRFs and myomiRs expression in young and senescent myoblasts during differentiation in vitro. Methods. Human skeletal muscle myoblast (HSMM) cells were cultured and serial passaging was carried out to obtain young and senescent cells. The cells were then treated with $C$. vulgaris followed by differentiation induction. The expression of Pax7, MyoD1, Myf5, MEF2C, IGF1R, MYOG, TNNT1, PTEN, and MYH2 genes and miR-133b, miR206, and miR-486 was determined in untreated and C. vulgaris-treated myoblasts on Days $0,1,3,5$, and 7 of differentiation. Results. The expression of Pax7, MyoD1, Myf5, MEF2C, IGF1R, MYOG, TNNT1, and PTEN in control senescent myoblasts was significantly decreased on Day 0 of differentiation ( $\mathrm{p}<0.05)$. Treatment with C. vulgaris upregulated Pax7, Myf5, MEF2C, IGF1R, MYOG, and PTEN in senescent myoblasts $(\mathrm{p}<0.05)$ and upregulated Pax7 and MYOG in young myoblasts $(\mathrm{p}<0.05)$. The expression of MyoD1 and Myf5 in young myoblasts however was significantly decreased on Day 0 of differentiation $(\mathrm{p}<0.05)$. During differentiation, the expression of these genes was increased with C. vulgaris treatment. Further analysis on myomiRs expression showed that miR-133b, miR-206, and miR-486 were significantly downregulated in senescent myoblasts on Day 0 of differentiation which was upregulated by $C$. vulgaris treatment $(\mathrm{p}<0.05)$. During differentiation, the expression of miR-133b and miR-206 was significantly increased with $C$. vulgaris treatment in both young and senescent myoblasts $(\mathrm{p}<0.05)$. However, no significant change was observed on the expression of miR-486 with C. vulgaris treatment. Conclusions. C. vulgaris demonstrated the modulatory effects on the expression of MRFs and myomiRs during proliferation and differentiation of myoblasts in culture. These findings may indicate the beneficial effect of C. vulgaris in muscle regeneration during ageing thus may prevent sarcopenia in the elderly.

\section{Introduction}

Muscle weakness and atrophy occur in ageing due to multifactorial degenerative processes. It is impacted by cellular ageing biology or primary ageing besides environmental and behavioral factors [1]. The term "sarcopenia" is derived from Greek words "sarx" and "penia", which mean flesh poverty.
It was first introduced by Rosenberg in 1988, in referring to the lean body mass loss in ageing $[2,3]$. The diagnosis of sarcopenia can be based on the presence of both low muscle mass and low gait speed [3]. Sarcopenia is also defined as the age-related decline of muscle mass, function, and/or strength, with high prevalence in ageing [4]. It has been reported that muscle strength loss at $2.5 \%$ to $3.0 \%$ per year in women and 
$3.0 \%$ to $4.0 \%$ per year in men, while muscle mass loss at $0.64 \%$ to $0.70 \%$ per year in women and $0.80 \%$ to $0.98 \%$ per year in men, in people aged 75 years [5].

Myogenesis is the process of myoblast cells generation which occurs during skeletal muscle tissue synthesis [6]. The satellite cell is important as it is the source of myogenic cells required for myofiber growth and repair throughout life. Proliferation of satellite cell gives rise to satellite cell-derived myoblasts that can differentiate and form multinucleated myotubes [7]. The myogenic regulatory factors (MRFs) are the member of the basic helix-loop-helix family of transcription factors that control the differentiation of skeletal muscle cells during regeneration of muscle [8]. The MRFs consist of four muscle-specific proteins that include Myf5, MyoD, Myogenin, and Myogenic Regulatory Factor 4 (MRF4). These proteins act at multiple points in the muscle lineage to cooperatively establish the skeletal muscle phenotype. It regulates precursor cell proliferation and cell cycle arrest and activates sarcomeric and muscle-specific genes to facilitate differentiation and sarcomere assembly [9].

The satellite cells remain in quiescent state under normal condition. However, when muscle is damaged, the satellite cells are activated and reenter cell cycle phases to produce muscle progenitor cells that are able to regenerate new muscle fibers. In ageing, the satellite cells as well as the systemic and niche environment undergo changes that affect the regenerative functions of the muscle. Aged satellite cells lose their reversible quiescent state due to the upregulation of gene encoding for $\mathrm{p} 16^{\mathrm{INK} 4 \mathrm{a}}$, a regulator protein of cellular senescence. Furthermore, the disruption of FGF2-Spryl1 signaling and delocalization of $\beta 1$-integrin in old satellite cells leads to the disturbance of quiescence state and induction of p16 ${ }^{\mathrm{INK} 4 \mathrm{a}}$ which provokes a switch of senescent-like state in becoming presenescent cells. This process will consequently impair the regeneration of skeletal muscle which includes activation, proliferation, and self-renewal of myoblasts [1012].

MicroRNAs (miRNAs) are evolutionary conserved, small RNAs with about 17 to 22 nucleotides. It plays vital roles in gene regulatory networks by binding and repressing the activity of specific target mRNAs. MicroRNA has shown its potential as biomarkers in diseases such as cancer $[13,14]$. miRNAs are also vital in the posttranscriptional control of gene expression $[15,16]$. Several types of miRNAs are highly expressed in different types of tissue and cell, with most of them being tissue-specific. A previous study reported that mature miRNA expression is 20 -fold higher than the mean expression of miRNA in other tissues indicating its specificity. Moreover, the expression of miRNA in tissue-enriched with mature miRNA is higher than in other tissues but less than 20-fold [17].

The miRNAs are divided into two categories: (1) miRNAs that are expressed specifically in muscle and not in other tissues known as myomiRs, and (2) miRNA that are expressed in nonmuscle tissue or broadly expressed in other cell types. The myomiRs are important in controlling skeletal muscle development and function as it may affect several biological pathways involved in myoblast proliferation, differentiation, and muscle regeneration $[14,18]$. Subsets of myomiRs can be categorized as striated muscle-specific (miR-1, miR-133a, miR-133b, miR-206, miR-208a, miR-208b, and mir-499) or muscle-enriched (miR-486). Some of the myomiRs are expressed in skeletal muscle as well as in cardiac muscle. However, miR-133b and miR-206 are skeletal muscle-specific, and miR-208a is cardiac muscle-specific [16].

World Health Organization (2015) reported that there will be an increase in the number of older population with age between 70 to 80 years in 2050 [19]. And among the major problems in the elderly, sarcopenia is of importance. Taking a natural remedy such as microalgae may be beneficial as one of the approaches in the prevention and management of this condition. Microalgae are believed to be first consumed by human 2000 years ago when the Chinese used bluegreen algae, Nostoc to survive during the scarcity of food [20]. Another alga, Chlorella, has been used in variety of biotechnology applications such as biodiesel production and biosorption of heavy metals [21-23]. Chlorella, a genus of unicellular green algae, is the most popular photosynthetic microalgae being studied and investigated currently.

A Dutch researcher, Martinus Willem Beijerinck, discovered C. vulgaris 129 years ago and described it as coccoid green algal "balls" with a well-defined nucleus $[23,24]$. The natural components found in C. vulgaris may be responsible for its pharmacological actions. Several studies reported $C$. vulgaris pharmacological effects, and this includes its antidiabetic [25, 26] and anticancer actions [27-29]. It also possesses highly nutritive contents such as carbohydrates, proteins, nucleic acids, chlorophylls, vitamins, and minerals [30] besides having $\beta$-carotene, lutein, chlorophyll-a, chlorophyllb, ascorbic acid, tocopherol, riboflavin, and retinol [31, 32]. In this study, we aimed to determine the effects of Chlorella vulgaris on the expression of genes and myomiRs involved in muscle differentiation of young and senescent myoblast cells in an attempt to elucidate the mechanism involved during myoblasts differentiation. The finding of this study may provide current information regarding the properties of C. vulgaris that can be used for the prevention of sarcopenia.

\section{Materials and Methods}

2.1. Cell Culture. Human Skeletal Muscle Myoblasts (HSMM) from 20 years old female Caucasian donor were purchased from Lonza (Walkersville, MD, USA). The skeletal muscle myoblasts were cultured in Skeletal Muscle Basal Medium (SkBM) with fetal bovine serum (FBS), L-glutamine, human epidermal growth factor (hEGF), dexamethasone, and gentamicin/amphotericin-B as supplements to the media (Lonza, Walkersville, MD, USA). Cells were cultivated at $37^{\circ} \mathrm{C}$ with $5 \% \mathrm{CO}_{2}$ atmosphere. The skeletal muscle myoblast cell then underwent serial passaging until it reached cellular senescence. The population doubling (PD) of the cell was calculated for each passage according to the formula $\ln (\mathrm{N} / \mathrm{n}) / \mathrm{ln}$ 2 as $\mathrm{N}$ is the number of cells at harvest stage and $\mathrm{n}$ is the number of cells at seeding stage [33]. The starting PD for this research was PD 8. The skeletal muscle myoblast cells reached cellular senescence when the cells were unable to proliferate in culture, even with consecutive replenishment. Myoblast cells were considered young at PD 14 and senescent at PD 21. 
TABLE 1: Sequence of primers used in gene expression analysis.

\begin{tabular}{|c|c|c|}
\hline Gene & Forward primer & Reverse primer \\
\hline GAPDH & $5^{\prime}$-TCCCTGAGCTGAACGGGAAG-3' & $5^{\prime}$-GGAGGAGTGGGTGTCGCTGT-3' \\
\hline $\operatorname{Pax} 7$ & 5'-GTGCCCTCAGTGAGTTCGAT-3' & $5^{\prime}$-GTTCCGACTCCACATCCGAG-3' \\
\hline Myf5 & $5^{\prime}$-TCACСТCСТCAGAGCAACCT-3' & $5^{\prime}$-ATTAGGCCCTCCTGGAAGAA-3' \\
\hline MyoD1 & $5^{\prime}$-AGGGGCTAGGTTCAGCTTTC-3' & $5^{\prime}$-GCTCTGGCAAAGCAACTCTT-3' \\
\hline MYOG & $5^{\prime}$-CAGTGCCATCCAGTACATCG-3' & $5^{\prime}$-AGGTTGTGGGCATCTGTAGG-3' \\
\hline PTEN & $\begin{array}{c}5^{\prime} \text {-ACTTGAAGGCGTATACAGGAC } \\
\text { CA- } 3^{\prime}\end{array}$ & $5^{\prime}$-AATGTCTTTCAGCACAAAGAT \\
\hline IGFIR & $5^{\prime}$-TGGAGTGCTGTATGCCTCTG-3' & $5^{\prime}$-СССТTGGCAACTCСТTCATA- $3^{\prime}$ \\
\hline$M E F 2 C$ & $5^{\prime}$-GGGGACTATGGGGAGAAAAA-3' & $5^{\prime}$-ACAGCTTGTTGGTGCTGTTG-3' \\
\hline MYH2 & $5^{\prime}$-CAAACATGAGAGGCGAGTGA-3' & 5'-CTGGAGCTTGCGGAATTTAG-3' \\
\hline TNNT1 & $5^{\prime}$-TGGAGCTGCAGACACTCATC-3' & 5'-CTTGGCCTCTTCCTCTTCCT-3' \\
\hline
\end{tabular}

2.2. Preparation of Chlorella vulgaris for Cell Treatment. Stock of C. vulgaris Beijerinck (strain 072) was obtained from the University of Malaya Algae Culture Collection (UMACC, Malaysia). The stock was grown in Bold's Basal Media (BBM) with a $12 \mathrm{~h}$ dark and $12 \mathrm{~h}$ light cycle. The algae were then harvested by centrifugation at $1000 \mathrm{rpm}$ and dried by using freeze dryer. Later, the algae were mixed in distilled water at a concentration of $10 \%(\mathrm{w} / \mathrm{v})$ and boiled at $100^{\circ} \mathrm{C}$ for $20 \mathrm{~min}$ by reflux method. The alga was centrifuged and lyophilized using a freeze dryer to obtain C. vulgaris in powder form $[29,30,34]$. Myoblast cells which were cultured in T25 culture flask were treated with C. vulgaris at concentrations of 10 and $100 \mu \mathrm{g} / \mathrm{ml}$ [34]. After plating the myoblasts for $24 \mathrm{~h}$ and the cells reached 70 to $80 \%$ confluency, the culture medium was replaced with $C$. vulgaris containing medium and left for $24 \mathrm{~h}$ in a $\mathrm{CO}_{2}$ incubator at $37^{\circ} \mathrm{C}$. The culture media were then replaced with differentiation medium and parameters were measured on Days $0,1,3,5$, and 7 of differentiation induction.

2.3. Immunofluorescence Staining of Myoblasts. Immunofluorescence staining on myoblasts in culture was performed using an antibody specific for desmin, at a dilution of 1:50 (D33; DAKO, Glostrup, Denmark). Skeletal myoblast cells were washed with phosphate-buffered saline (PBS) and fixed in $100 \%$ cold ethanol, followed by incubation in $1 \%$ fetal bovine serum (FBS). The skeletal myoblast cells were washed again with PBS and incubated consequently with anti-desmin monoclonal antibody (D33, DAKO, Glostrup, Denmark) and Alexa Flour 488 goat anti-mouse in dark environment (Life Technologies, Carlsbad, CA, USA) with PBS washing in between the two antibodies incubation. Cell nuclei were visualized by Hoechst 33342 (Life Technologies, Carlsbad, CA, USA). The desmin staining was viewed under EVOS FL Digital Inverted Fluorescence Microscope (Life Technologies, Carlsbad, CA, USA). The morphological changes of the myoblast cell were observed throughout the differentiation days.

2.4. Induction of Myogenic Differentiation. For induction of muscle cell differentiation, the proliferation medium SkBM was replaced with a differentiation medium; DMEM: F12
(Lonza, Walkersville, MD, USA) with supplementation of $2 \%$ horse serum (ATCC, Baltimore, USA). The differentiation medium was changed every two days until the desired day of differentiation for RNA extraction.

2.5. RNA Extraction. The extraction of RNA was carried out on Days $0,1,3,5$, and 7 of differentiation. Total RNA was isolated using TRI ${ }^{\circledR}$ reagent (Molecular Research Center Inc, Ohio, USA) on Days $0,1,3,5$, and 7 of differentiation. A total of $2 \mathrm{ml}$ TRI reagent was added to $25 \mathrm{~cm}^{2}$ culture flask of seeding cells and left for 2 min prior to aliquot into microcentrifuge tube. Chloroform was added at $200 \mu \mathrm{l}$ and vortex before being left at room temperature for $15 \mathrm{~min}$, followed by vortex at $12000 \mathrm{~g}$ and $4^{\circ} \mathrm{C}$, for $15 \mathrm{~min}$. The resultant clear layer of RNA was transferred into another new tube prior adding $500 \mu \mathrm{l}$ isopropanol and $5 \mu \mathrm{l}$ poly acryl carrier and left at room temperature for $5 \mathrm{~min}$ before centrifuged at $12000 \mathrm{~g}$ and $4^{\circ} \mathrm{C}$ for $8 \mathrm{~min}$. The supernatant was removed and the RNA pellet was cleaned with $1 \mathrm{ml}$ of $75 \%$ ethanol, followed by centrifuged at $7500 \mathrm{~g}$ and $4^{\circ} \mathrm{C}$, for $5 \mathrm{~min}$. Supernatant was further removed and RNA pellet was left to dry for about $20 \mathrm{~min}$ by directing the open tube to the laminar flow chamber. The dried pellet was later dissolved in $20 \mu \mathrm{l}$ RNase-free water (Life Technologies, New York, USA) and vortexed to be further kept at $-80^{\circ} \mathrm{C}$.

2.6. RNA Purity and Concentration. The purity of the extracted RNA was determined by Nanodrop 2000c Spectrophotometer (Thermo Scientific, USA). The extracted RNA with A260/280 value in a range of 1.8 to 2.0 was considered pure and used in gene and myomiRs expression analysis.

2.7. Primer Design. The primer of desired genes was designed from the National Center for Biotechnology Information (NCBI) gene bank. All of the primers used in gene expression analysis were synthesized by Integrated DNA Technologies, Inc. (Illinois, USA) except the primers for Pax7, which was synthesized from Bio Basic Inc. (Markham, ON, Canada) (Table 1). The target sequences for myomiRs expression analysis were synthesized by Life Technologies Corporation (Texas, USA) (Table 2). 
TABLE 2: The targeted sequence used in myomiRs expression analysis.

\begin{tabular}{lcc}
\hline miRNA primer & Assay ID & Target sequence \\
\hline hsa-miR-133b & $480871 \_m i r$ & $5^{\prime}$-UUUGGUCCCCUUCAACCAGCUA-3' \\
hsa-miR-206 & $477968 \_m i r$ & $5^{\prime}$-UGGAAUGUAAGGAAGUGUGUGG-3' \\
hsa-miR486-5p & $478128 \_\mathrm{mir}$ & $5^{\prime}$-UCCUGUACUGAGCUGCCCCGAG-3' \\
hsa-miR-191-5p & $477952 \_\mathrm{mir}$ & $5^{\prime}$-CAACGGAAUCCCAAAAGCAGCUG-3' \\
\hline
\end{tabular}

2.8. Gene Expression Analysis. Gene expression analysis was carried out by using KAPA SYBR ${ }^{\circledR}$ FAST Bio-Rad iCycler ${ }^{\circledR}$ One-Step RT-qPCR Kit (Kapa Biosystems Pty. Ltd., Boston, Massachusetts, USA) according to manufacturer's instructions. The PCR mixture was prepared by mixing $0.3 \mu \mathrm{l}$ RT mix, $9 \mu \mathrm{l}$ master mix, $12.7 \mu \mathrm{l}$ RNase-free water, $1.0 \mu \mathrm{l}$ of 100 $\mu \mathrm{M}$ forward primer, and $1.0 \mu \mathrm{l}$ of $100 \mu \mathrm{M}$ reverse primer of desired gene. A volume of $24 \mu \mathrm{l}$ PCR mixture was added to the desired well of 96-well PCR plate and $1 \mu$ l of total RNA sample was also added. The 96-well plate was placed in CFX96 Touch ${ }^{\mathrm{TM}}$ Real-Time PCR Detection System (Biorad, California, USA). The protocol of one-step RT-qPCR was cDNA synthesis at $42^{\circ}$ for $5 \mathrm{~min}$, inactivation of reversetranscriptase (RT) at $95^{\circ} \mathrm{C}$ for $4 \mathrm{~min}$, followed by 40 cycles of $95^{\circ} \mathrm{C}$ for $3 \mathrm{sec}$ and $53^{\circ} \mathrm{C}$ for $20 \mathrm{sec}$. The melting curve and data analysis were then generated at $95^{\circ} \mathrm{C}$ for a minute, $95^{\circ} \mathrm{C}$ for $30 \mathrm{sec}, 55^{\circ} \mathrm{C}$ for a min, and $81 \mathrm{cycles}$ of $55^{\circ} \mathrm{C}$ to $95^{\circ} \mathrm{C}$ for $10 \mathrm{sec}$. Primer specificity was then determined from the melting curve produced. All values of the threshold cycle (Ct value) obtained were normalized with the reference gene GAPDH. Relative expression value (REV) was calculated based on the relative quantitative method $2^{-(\Delta \mathrm{Ct})}$ [35] by (1):

$\mathrm{REV}=2^{\text {(The value of GAPDH Ct-The value of the target gene } \mathrm{Ct} \text { ). }}$

2.9. MyomiRs Expression Analysis. The determination of miRNA expression was carried out by using TaqMan ${ }^{\circledR}$ Advanced miRNA Assays (Life Technologies Corporation, Texas, USA) based on the manufacturer's protocol. The poly (A) tailing reaction was prepared firstly by mixing $2 \mu \mathrm{l}$ of total RNA sample and poly (A) reaction mix in reaction tubes, consisting of $0.5 \mu \mathrm{l} 10 \mathrm{X}$ poly (A) buffer, $0.5 \mu \mathrm{l}$ ATP, $0.3 \mu \mathrm{l}$ poly (A) enzyme, and $1.7 \mu$ l RNase-free water, which was then incubated in the thermal cycler for polyadenylation at $37^{\circ} \mathrm{C}$ for $45 \mathrm{~min}$ and stop reaction at $65^{\circ} \mathrm{C}$ for $10 \mathrm{~min}$. Then, adaptor ligation reaction was performed by adding the ligation reaction mix which contains $3 \mu \mathrm{l}$ X DNA ligase buffer, $4.5 \mu \mathrm{l}$ 50\% PEG 8000, $0.6 \mu \mathrm{l}$ 25X ligation adaptor, $1.5 \mu \mathrm{l}$ RNA ligase, and $0.4 \mu \mathrm{l}$ RNase-free water, into the reaction tubes containing poly (A) tailing reaction product and incubated for ligation at $16^{\circ} \mathrm{C}$ for $60 \mathrm{~min}$. This is followed by RT reaction by adding the RT reaction mix, consisting of $6 \mu \mathrm{l}$ 5X RT buffer, 1.2 $\mu \mathrm{l}$ dNTP mix, $1.5 \mu \mathrm{l}$ 20X universal RT primer, $3 \mu \mathrm{l}$ 10X RT enzyme mix, and $3.3 \mu \mathrm{l}$ RNase-free water, into the reaction tubes which contain the adaptor ligation reaction product and incubated for RT reaction at $42^{\circ} \mathrm{C}$ for $15 \mathrm{~min}$ and stop reaction at $85^{\circ} \mathrm{C}$ for $5 \mathrm{~min}$. The $\mathrm{miR}$-Amp reaction was then continued by mixing miR-Amp reaction mix containing $25 \mu \mathrm{l}$ 2X miR-Amp master mix, $2.5 \mu \mathrm{l} 20 \mathrm{X}$ miR-Amp primer mix, and $17.5 \mu \mathrm{l}$ RNase-free water and RT reaction product and incubated for enzyme activation at $95^{\circ} \mathrm{C}$ for $5 \mathrm{~min}, 14$ cycles of denaturation at $95^{\circ} \mathrm{C}$ for $3 \mathrm{sec}$, and annealing/extension at $60^{\circ} \mathrm{C}$ for $30 \mathrm{sec}$ and stop reaction at $99^{\circ} \mathrm{C}$ for $10 \mathrm{~min}$. The miR-Amp reaction product was further subjected to RTPCR reaction. A total of $5 \mu \mathrm{l}$ diluted cDNA template was mixed with $10 \mu \mathrm{l}$ Taqman ${ }^{\circledR}$ Fast Advanced Master Mix, $1 \mu \mathrm{l}$ Taqman ${ }^{\circledR}$ Advanced miRNA Assay, and $4 \mu \mathrm{l}$ RNase-free water and run for enzyme activation at $95^{\circ} \mathrm{C}$ for $20 \mathrm{sec}$ and 40 cycles of denaturation at $95^{\circ} \mathrm{C}$ for $3 \mathrm{sec}$ and annealing/extension at $60^{\circ} \mathrm{C}$ for $30 \mathrm{sec}$. Data of the threshold cycle (Ct value) acquired was normalized with the reference endogenous control hsa-miR-191-5p. The relative expression value (REV) was then calculated based on the relative quantitative method $2^{-(\Delta \mathrm{Ct})}$.

2.10. Statistical Analysis. Data obtained were expressed as mean \pm SD and statistical analysis was carried out using SPSS software version 23. Data were analysed using oneway ANOVA followed by Tukey's post hoc test for multiple comparison. Value of $\mathrm{p}<0.05$ was considered statistically significant.

\section{Results}

3.1. Immunofluorescence Staining of Myoblasts. Myoblast cells at young stage were spindle-shaped with less branches and underwent changes in morphology at senescent stage on Day 0 of differentiation. Senescent myoblast cells were larger and flatter with the presence of prominent intermediate filaments and single nuclei for each myoblast (Figure 1). Throughout the differentiation days, C. vulgaris-treated young and senescent myoblast cells were observed to differentiate, as notably indicated by the fusion of nuclei per myotube on Day 3 of differentiation and more formation of myotubes on Day 7 compared to Day 0 of differentiation. However, the differentiation of senescent myoblasts was observed to be less efficient as compared to young myoblasts for both the untreated and C. vulgaris-treated cells.

3.2. Gene Expression at Day 0 of Differentiation. On Day 0 of differentiation, Pax7, MyoD1, Myf5, MEF2C, IGF1R, MYOG, TNNT1, and PTEN were significantly downregulated in control senescent myoblasts as compared to control young myoblasts $(\mathrm{p}<0.05)$ (Figures $2(\mathrm{a})-2(\mathrm{i}))$. However, Pax7 was significantly upregulated on Day 0 of differentiation with $100 \mu \mathrm{g} / \mathrm{ml} \mathrm{C}$. vulgaris treatment in young myoblasts $(\mathrm{p}<0.05)$ (Figure 2(a)). A similar increase was observed in the expression of Pax7 (Figure 2(a)) and Myf5 (Figure 2(c)) in senescent myoblasts treated with $10 \mu \mathrm{g} / \mathrm{ml}$ and $100 \mu \mathrm{g} / \mathrm{ml} C$. vulgaris $(\mathrm{p}<0.05)$. Decreased MyoD1 (Figure 2(b)) and Myf5 


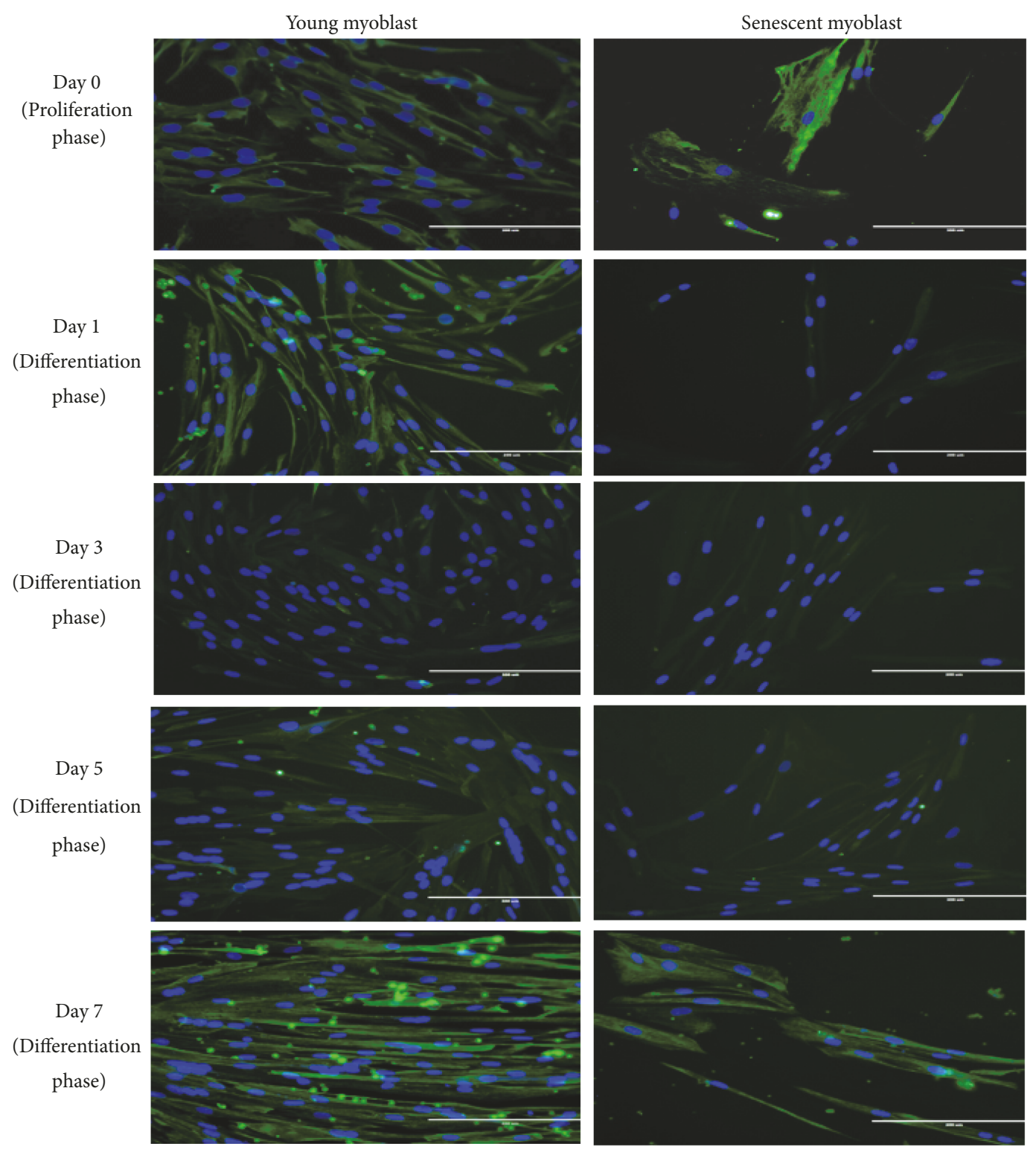

FIGURE 1: Effects of C. vulgaris treatment on desmin staining on Days $0,1,3,5$, and 7 of differentiation for young and senescent myoblast. The photomicrographs of desmin staining of $C$. vulgaris-treated myoblast cells further elucidated differentiation of myoblasts with the presence of multinucleated cells and more formation of myotubes on Day 7 as compared to Day 0 of differentiation. Myoblasts cells were stained green for desmin and blue for nuclei (Magnification: 200x).

(Figure 2(c)) were observed in young myoblasts treated with both $10 \mu \mathrm{g} / \mathrm{ml}$ and $100 \mu \mathrm{g} / \mathrm{ml} \mathrm{C.} \mathrm{vulgaris}(\mathrm{p}<0.05)$. Treatment with $100 \mu \mathrm{g} / \mathrm{ml} \mathrm{C.} \mathrm{vulgaris} \mathrm{in} \mathrm{senescent} \mathrm{myoblasts} \mathrm{signifi-}$ cantly increased the expression of $M E F 2 C$ (Figure 2(d)) and MYOG (Figure 2(f)) ( $<<0.05)$. MYOG was also significantly upregulated in young myoblasts with both $10 \mu \mathrm{g} / \mathrm{ml}$ and $100 \mu \mathrm{g} / \mathrm{ml} \mathrm{C}$. vulgaris treatment $(\mathrm{p}<0.05)$ (Figure $2(\mathrm{f})) . C$. vulgaris treatment at $10 \mu \mathrm{g} / \mathrm{ml}$ in senescent myoblast significantly increased the expression of IGF1R (Figure 2(e)) and PTEN (Figure 2(h)) compared to control senescent myoblasts $(\mathrm{p}<0.05)$. The expression of TNNT1 and MYH2 however was not affected by $C$. vulgaris treatment in both young and senescent myoblasts (Figures 2(g)-2(i)).
3.3. Gene Expression on Days 1, 3, 5, and 7 of Differentiation. Pax7 was significantly upregulated in control young myoblasts on Days 5 and 7 of differentiation (Figure 2(j)) while $M y o D 1$ in control young myoblasts was significantly upregulated on Day 5 of differentiation as compared to Day $0(\mathrm{p}<0.05)($ Figure $2(\mathrm{k}))$. The expression of $M y f 5$ was decreased in control young myoblasts on Days $1,3,5$, and 7 of differentiation as compared to Day 0 (Figure 2(l)) while $M E F 2 C$ in control young myoblasts was upregulated on Day 7 of differentiation $(\mathrm{p}<0.05)$ (Figure $2(\mathrm{~m})$ ). No significant change was observed on the expression of IGF1R (Figure 2(n)) and MYH2 (Figure 2(r)) on Day 1 till Day 7 of differentiation in control young myoblasts compared to Day 0 


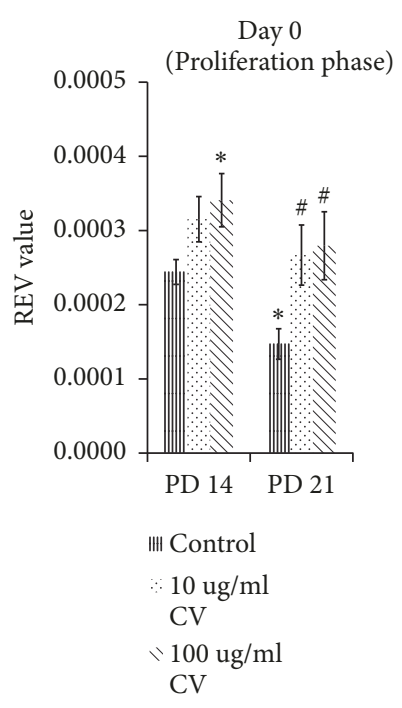

(a) $\operatorname{Pax} 7$

Day 0

(Proliferation phase)

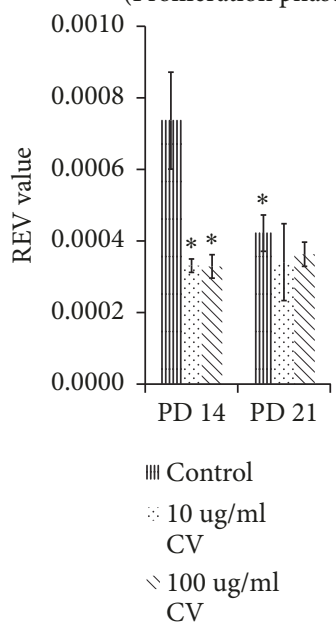

(b) $M y o D 1$

Day 0

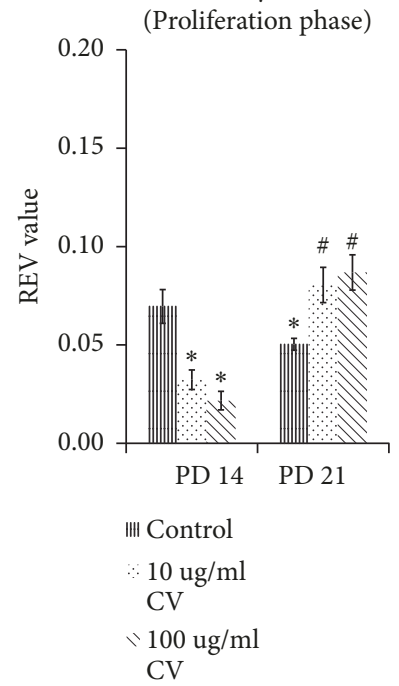

(c) Myf5

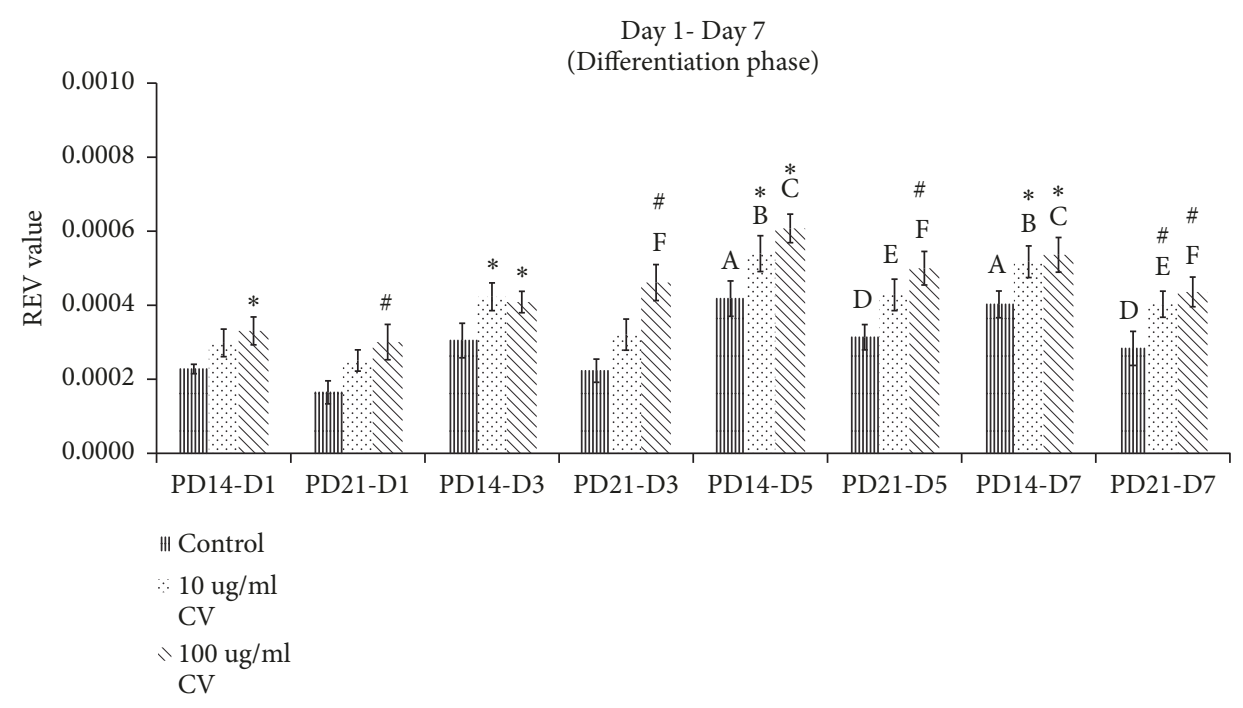

(j) $\operatorname{Pax} 7$

Day 1- Day 7

(Differentiation phase)

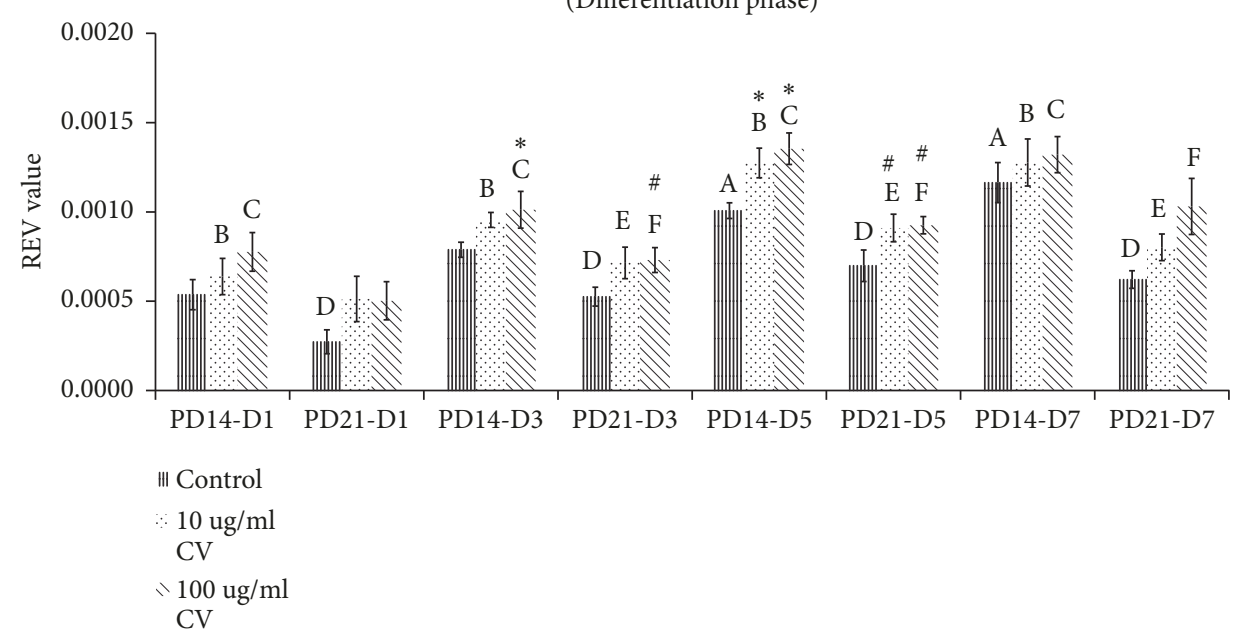

(k) $M y o D 1$

Day 1- Day 7

(Differentiation phase)

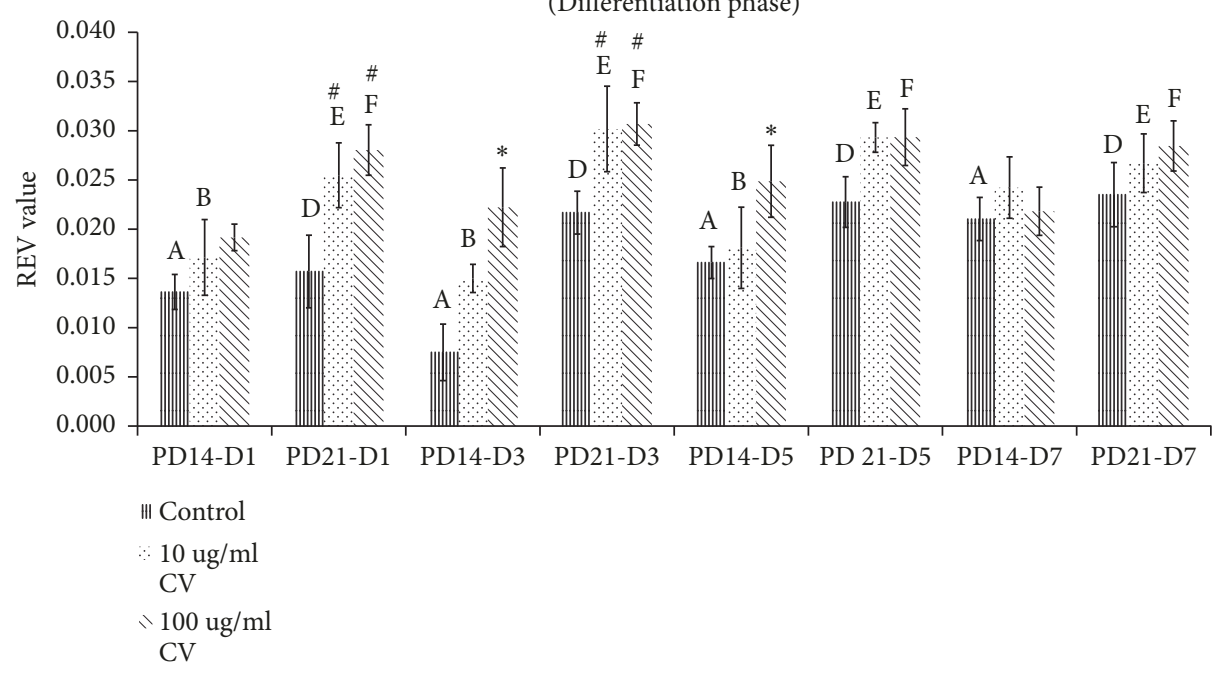

(l) Myf5

FIGURE 2: Continued. 


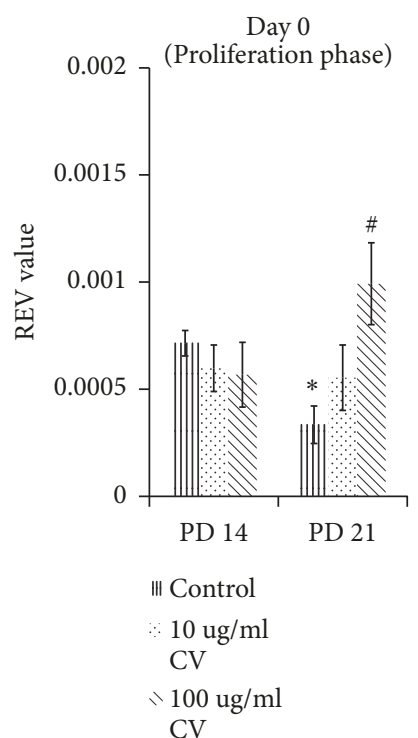

(d) $M E F 2 C$

Day 0

(Proliferation phase)

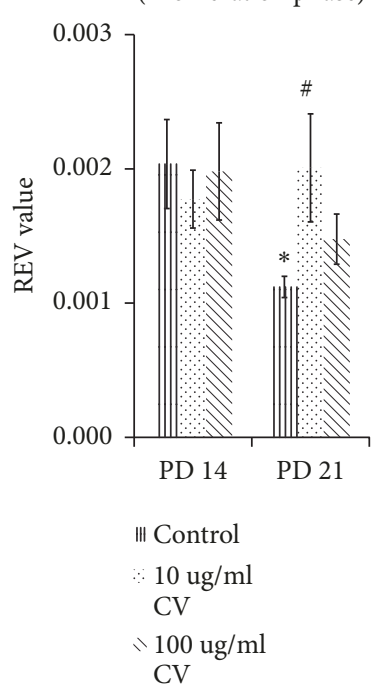

(e) IGF1R

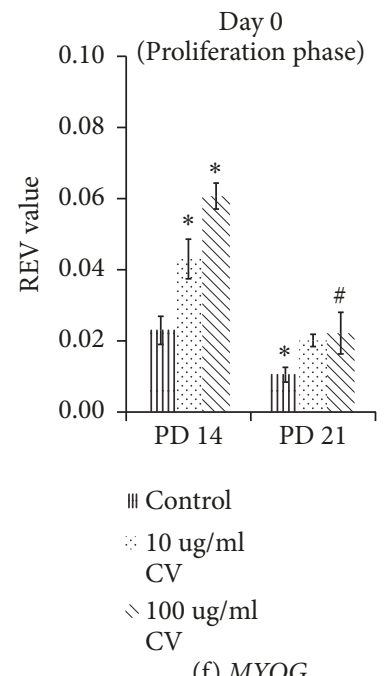

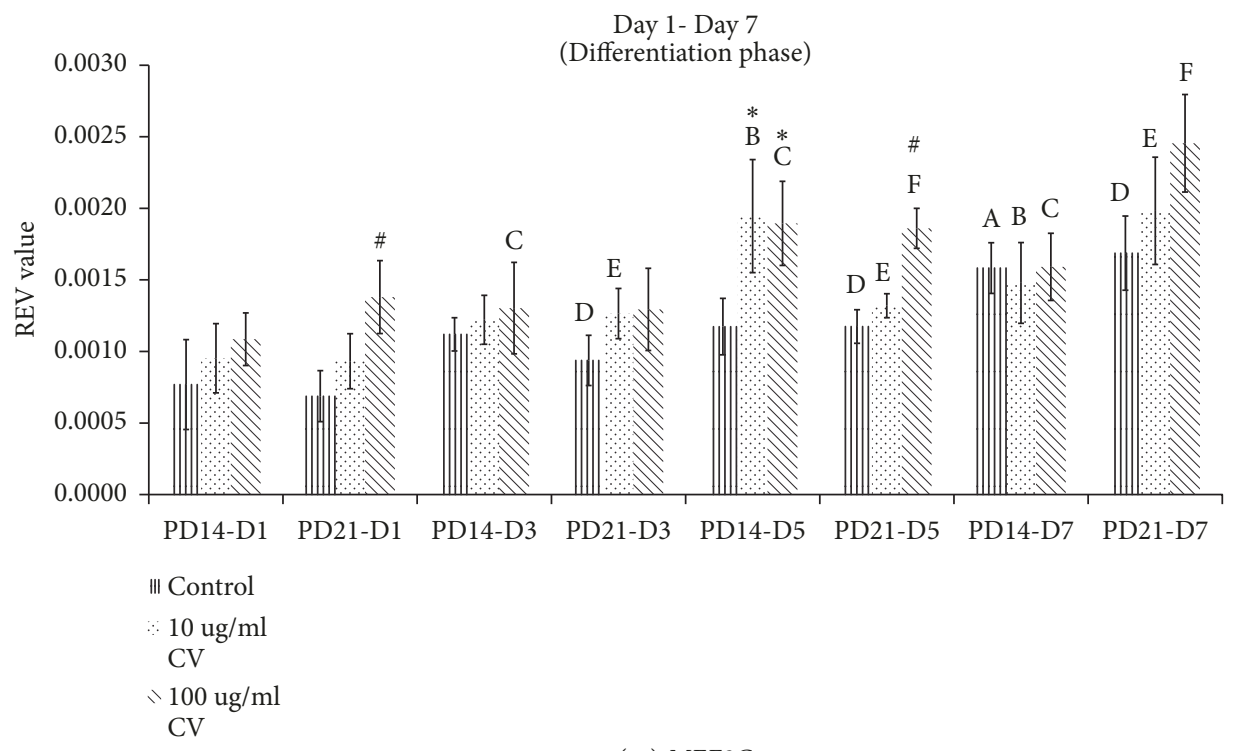

(m) MEF2C

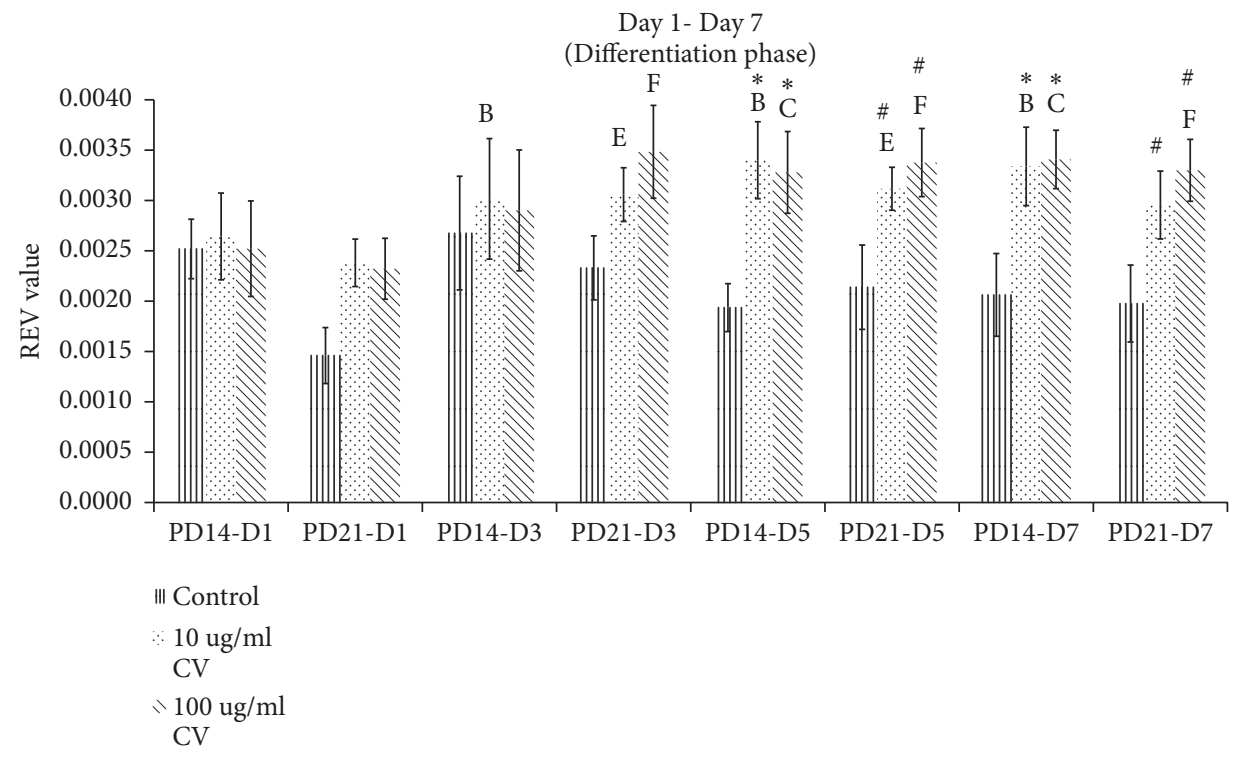

(n) IGF1R

Day 1- Day 7

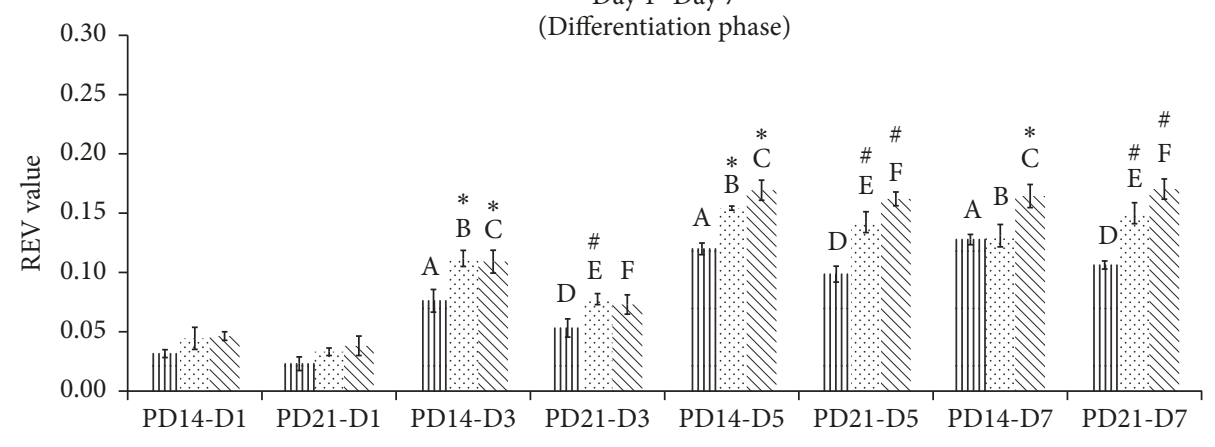

II Control

$10 \mathrm{ug} / \mathrm{ml}$

$\mathrm{CV}$

$\therefore 100 \mathrm{ug} / \mathrm{ml}$

CV

(o) MYOG

Figure 2: Continued. 


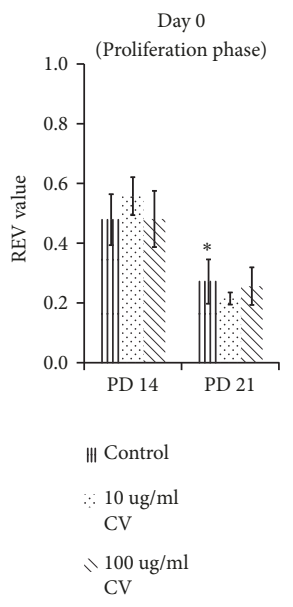

(g) TNNT1

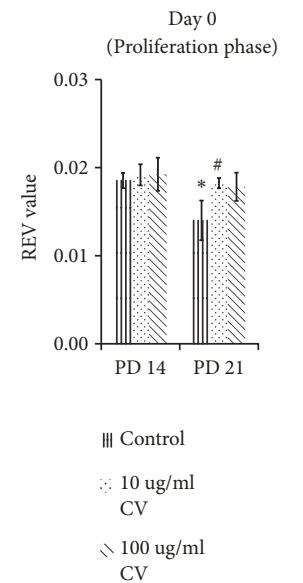

(h) PTEN

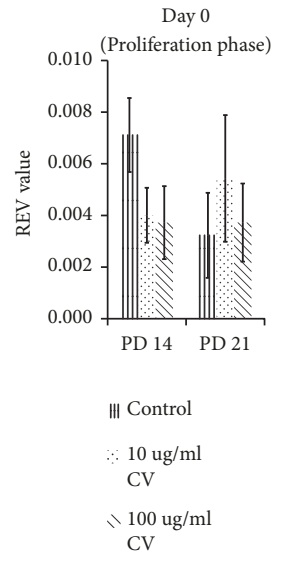

(i) $M Y H 2$

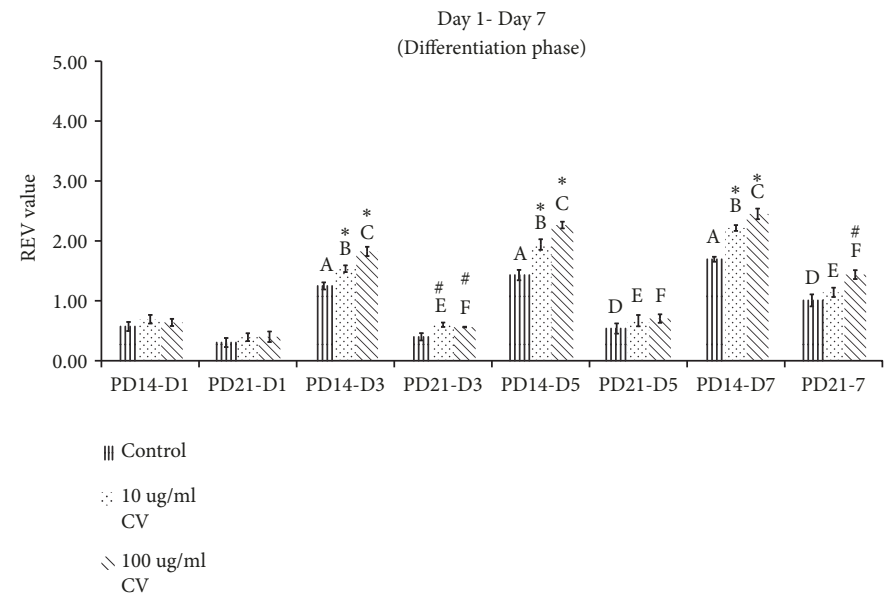

(p) TNNT1

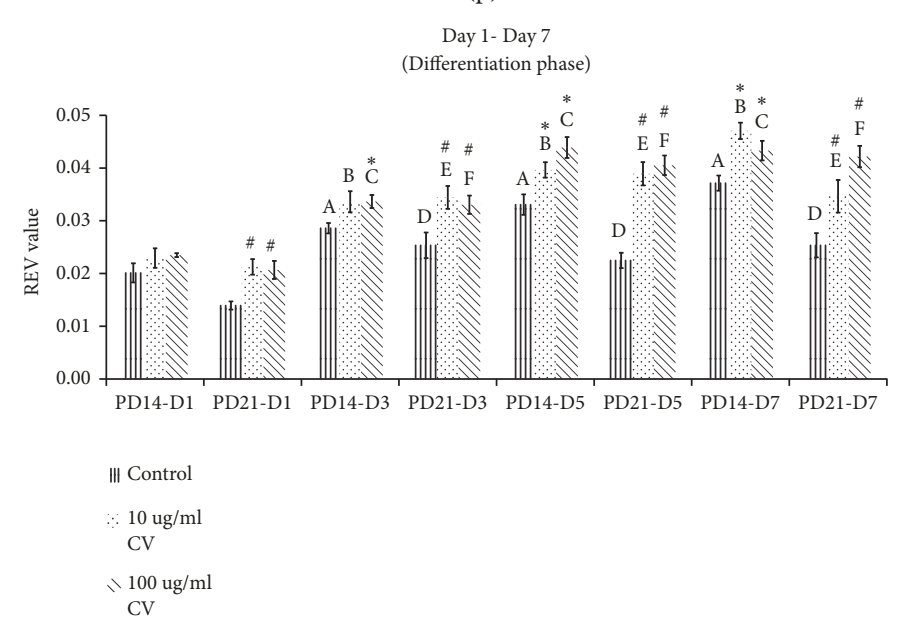

(q) PTEN

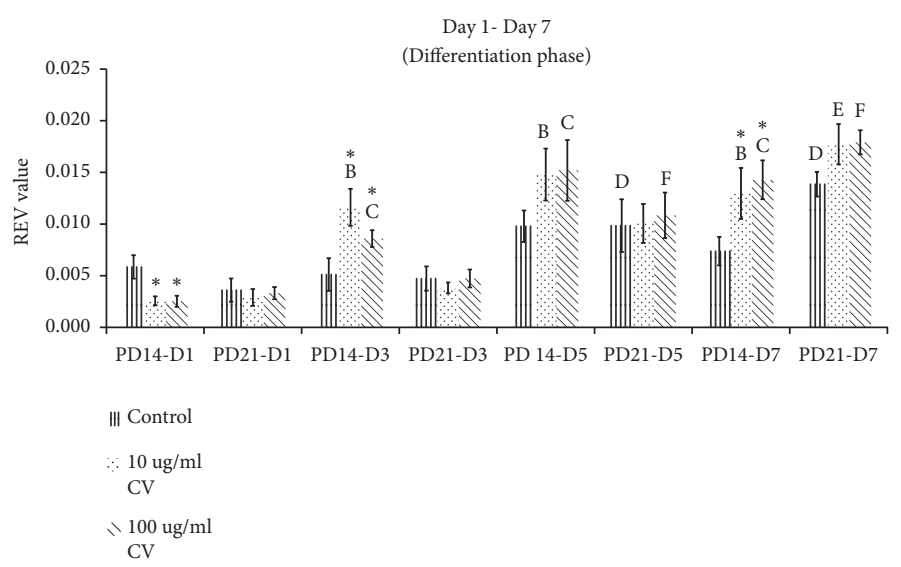

(r) $M Y H 2$

FIGURE 2: Effects of C. vulgaris treatment on the gene expression on Day 0 of differentiation (a-i) and Days 1, 3, 5, and 7 of differentiation (j-r). The expression of gene was determined in control and C. vulgaris-treated young and senescent myoblasts. The data are presented as the means $\pm \mathrm{SD}, \mathrm{n}=3 . * \mathrm{p}<0.05$ significantly different compared to control young on respective day, ${ }^{\#} \mathrm{p}<0.05$ significantly different compared to control senescent on respective day, ${ }^{A} \mathrm{p}<0.05$ significantly different compared to control young on Day $0,{ }^{\mathrm{B}} \mathrm{p}<0.05$ significantly different compared to young treated with $10 \mu \mathrm{g} / \mathrm{ml} \mathrm{C.} \mathrm{vulgaris} \mathrm{on} \mathrm{Day} 0,{ }^{C} \mathrm{p}<0.05$ significantly different compared to young treated with $100 \mu \mathrm{g} / \mathrm{ml} C$. vulgaris on Day $0,{ }^{D} \mathrm{p}<0.05$ significantly different compared to control senescent on Day $0,{ }^{\mathrm{E}} \mathrm{p}<0.05$ significantly different compared to senescent treated with $10 \mu \mathrm{g} / \mathrm{ml} \mathrm{C.} \mathrm{vulgaris} \mathrm{on} \mathrm{Day} 0$, and ${ }^{\mathrm{F}} \mathrm{p}<0.05$ significantly different compared to senescent treated with $100 \mu \mathrm{g} / \mathrm{ml}$ C. vulgaris on Day 0 , with a post hoc Tukey HSD test. 
of differentiation. The expression of MYOG (Figure 2(o)) and PTEN (Figure 2(q)) in control young myoblasts was significantly increased on Days 3, 5, and 7 of differentiation while TNNT1 in control young myoblasts was significantly upregulated on Day 3 of differentiation as compared to Day 0 of differentiation $(\mathrm{p}<0.05)$ (Figure $2(\mathrm{p})$ ).

In control senescent myoblasts, an upregulation of Pax7 (Figure 2(j)), TNNT1 (Figure 2(p)), and MYH2 (Figure 2(r)) was observed on Days 5 and 7 of differentiation while MyoD1 (Figure 2(k)) and Myf5 (Figure 2(1)) were upregulated on Days 1, 3, 5, and 7 of differentiation, and MEF2C (Figure 2(m)), MYOG (Figure 2(o)), and PTEN (Figure 2(q)) were upregulated on Days 3, 5, and 7 of differentiation compared to Day $0(\mathrm{p}<0.05)$. No significant change was observed in the expression of IGFIR in control senescent myoblasts on Day 1 till Day 7 of differentiation compared to Day 0 (Figure 2(n)).

Treatment with $10 \mu \mathrm{g} / \mathrm{ml}$ and $100 \mu \mathrm{g} / \mathrm{ml} \mathrm{C.} \mathrm{vulgaris} \mathrm{was}$ found to upregulated Pax7 in young myoblasts on Days 3, 5 , and 7 of differentiation and in senescent myoblasts on Day 7 of differentiation $(\mathrm{p}<0.05)$ (Figure $2(\mathrm{j}))$; upregulated MyoD1 in both young and senescent myoblasts on Day 5 of differentiation $(\mathrm{p}<0.05)$ (Figure $2(\mathrm{k})$ ); upregulated Myf5 in senescent myoblasts on Day 1 and 3 of differentiation $(\mathrm{p}<0.05)$, (Figure 2(l)); upregulated MEF2C in both young and senescent myoblasts on Day 5 of differentiation $(\mathrm{p}<0.05)$ (Figure 2(m)); upregulated IGF1R in both young and senescent myoblasts on Days 5 and 7 of differentiation $(\mathrm{p}<0.05)$ (Figure 2(n)); upregulated MYOG in young myoblasts on Days 3 and 5 of differentiation and in senescent myoblasts on Days 5 and 7 of differentiation $(\mathrm{p}<0.05)$ (Figure 2(o)); upregulated TNNT1 in young myoblasts on Days 3, 5, and $7(\mathrm{p}<0.05)$ (Figure 2(p)); upregulated PTEN in young myoblasts on Days 5 and 7 of differentiation and in senescent myoblasts on Days 1, 3, 5, and 7 of differentiation $(\mathrm{p}<0.05)$ (Figure 2(q)); downregulated $M Y H 2$ in young myoblasts on Day 1 of differentiation and upregulated $M Y H 2$ in young myoblasts on Days 3 and 7 of differentiation as compared to control $(\mathrm{p}<0.05)$ (Figure 2(r)).

3.4. MyomiRs Expression on Day 0 of Differentiation. The expression of miR-133b, miR-206, and miR-486 in control senescent myoblasts was significantly decreased as compared to control young myoblasts $(\mathrm{p}<0.05)$ (Figures $3(\mathrm{a})-3(\mathrm{c}))$. A similar decrease in the expression of miR-133b, miR-206, and miR-486 in young myoblasts was observed with C. vulgaris treatment at $10 \mu \mathrm{g} / \mathrm{ml}$ and $100 \mu \mathrm{g} / \mathrm{ml}$ compared to control young $(\mathrm{p}<0.05)$. In senescent myoblasts however, treatment with $10 \mu \mathrm{g} / \mathrm{ml} \mathrm{C.} \mathrm{vulgaris} \mathrm{was} \mathrm{found} \mathrm{to} \mathrm{increase} \mathrm{the} \mathrm{expression}$ of miR-133b, miR-206, and miR-486 compared to control senescent $(\mathrm{p}<0.05)$ (Figures 3(a)-3(c)).

3.5. MyomiRs Expression on Days 1, 3, 5, and 7 of Differentiation. In control young myoblasts, the expression of miR-133b was significantly decreased on Days $1,3,5$, and 7 of differentiation compared to Day $0(\mathrm{p}<0.05)$ (Figure 3(d)). However, no significant change was observed in the expression of miR133b in control senescent myoblasts on Day 1 till Day 7 of differentiation. A similar reduction in the expression of miR206 in control young myoblasts was observed on Days 1, 3, 5 , and 7 of differentiation as compared to Day $0(\mathrm{p}<0.05)$ (Figure 3(e)) with no significant change being observed in control senescent myoblasts. The expression of miR-486 was not significantly changed in both control young and control senescent myoblasts (Figure 3(f)). Treatment with $10 \mu \mathrm{g} / \mathrm{ml}$ C. vulgaris significantly increased the expression of miR-133b and miR-206 in senescent myoblasts on Day 3 of differentiation compared to control $(\mathrm{p}<0.05)$ (Figures 3(d)-3(e)). Expression of miR-206 in young and senescent myoblasts was increased on Day 1 of differentiation with $100 \mu \mathrm{g} / \mathrm{ml}$ C. vulgaris treatment compared to control $(\mathrm{p}<0.05)$ (Figure 3(e)). $100 \mu \mathrm{g} / \mathrm{ml} \mathrm{C.} \mathrm{vulgaris} \mathrm{treatment} \mathrm{also} \mathrm{increased}$ mir-206 expression in senescent myoblasts on Day 3 of differentiation compared to control $(\mathrm{p}<0.05)$. No significant change was observed in the expression of miR-486 with C. vulgaris treatment in young and senescent myoblasts (Figure 3(f)).

\section{Discussion}

Several mechanisms may contribute to sarcopenia and decrease the ability to reverse muscle atrophy in ageing. This includes decreased protein synthesis, reduction in neural function, hormonal deficit, chronic inflammation, oxidative stress, loss of mitochondrial function, inappropriate signaling in muscle due to inadequate nutrition, nuclear apoptosis, and reduction in satellite cell function [36]. In aged and sarcopenic muscles, satellite cell proliferation and differentiation may be diminished and consequently cause the decline in the regenerative potential. Modification in satellite cell function may affect differentiation and fusion of myoblast cells. It has been reported that, in senescent satellite cells, the level of MyoD protein and its DNA-binding activity were significantly reduced and delayed compared to young cells $[33,36]$ indicating the effect of ageing on myogenic regulatory factors (MFRs). Thus, elucidation of the mechanism involved is vital so that targeted intervention can be proposed.

The MRFs genes such as myogenic differentiation 1 protein (MyoD1), myogenic factor 5 (Myf5), myogenin (MYOG), and muscle-specific regulatory factor 4 (Mrf4) are myogenic specific which act for the activation of satellite cells [36]. The paired box protein (PAX7) controls the regulation of MYF5 and MYOD1 protein expression upon activation of quiescent satellite cells. The results of this study showed that the expression of IGF1R, MEF2C, Myf5, MyoD1, MYOG, Pax7, TNNT1, and PTEN was significantly decreased in control senescent myoblast cells as compared to control young myoblast cells on Day 0 of differentiation indicating downregulation of these genes during replicative senescence or cellular senescence of myoblast cells. The decrease in regenerative potential of aged muscles was reported to be associated with the reduction in satellite cell function and declined Pax7 pool of myogenic stem cells [36]. Another study reported that $P a x 3, P a x 7, M y f 5, M y o D$, and $M Y O G$ were significantly downregulated in the myoblasts extracted from elderly subjects compared to young subjects [37]. However, 


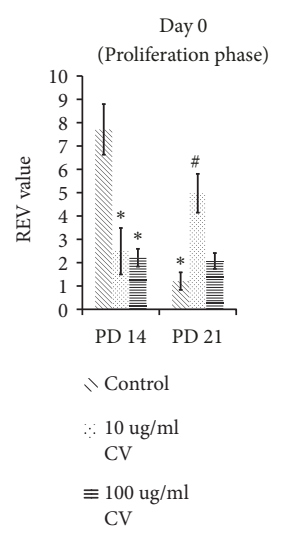

(a) $\mathrm{miR}-133 \mathrm{~b}$

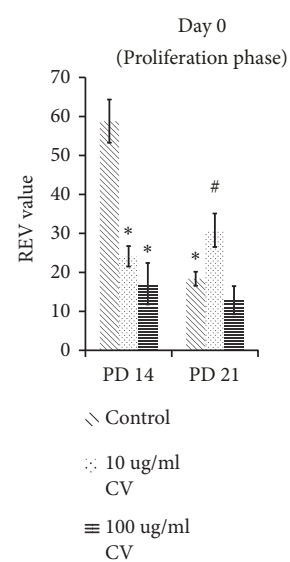

(b) miR-206

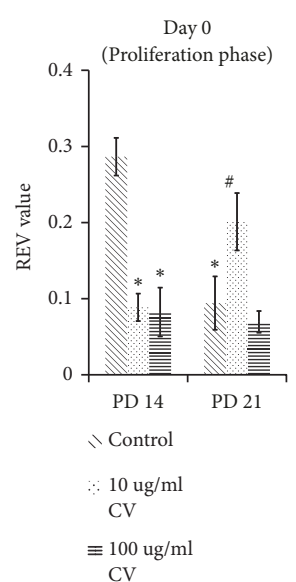

(c) $\operatorname{miR}-486$

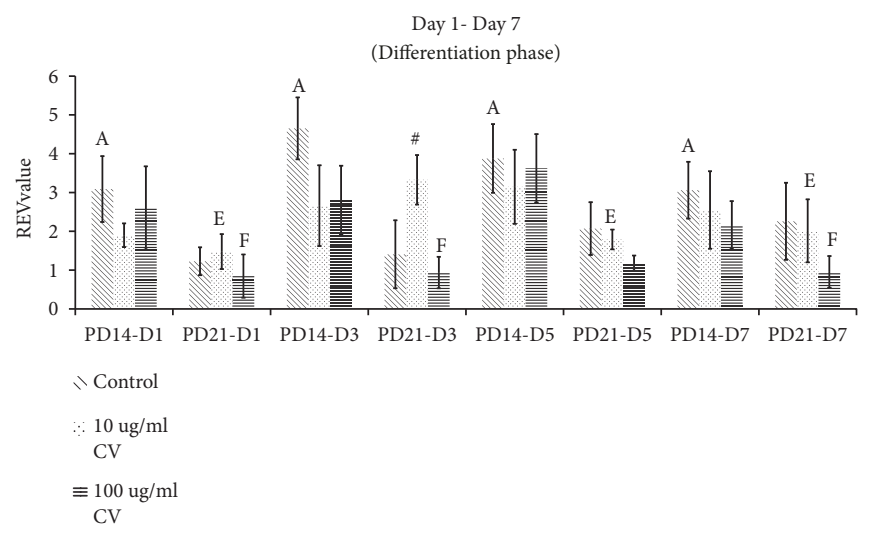

(d) miR-133b
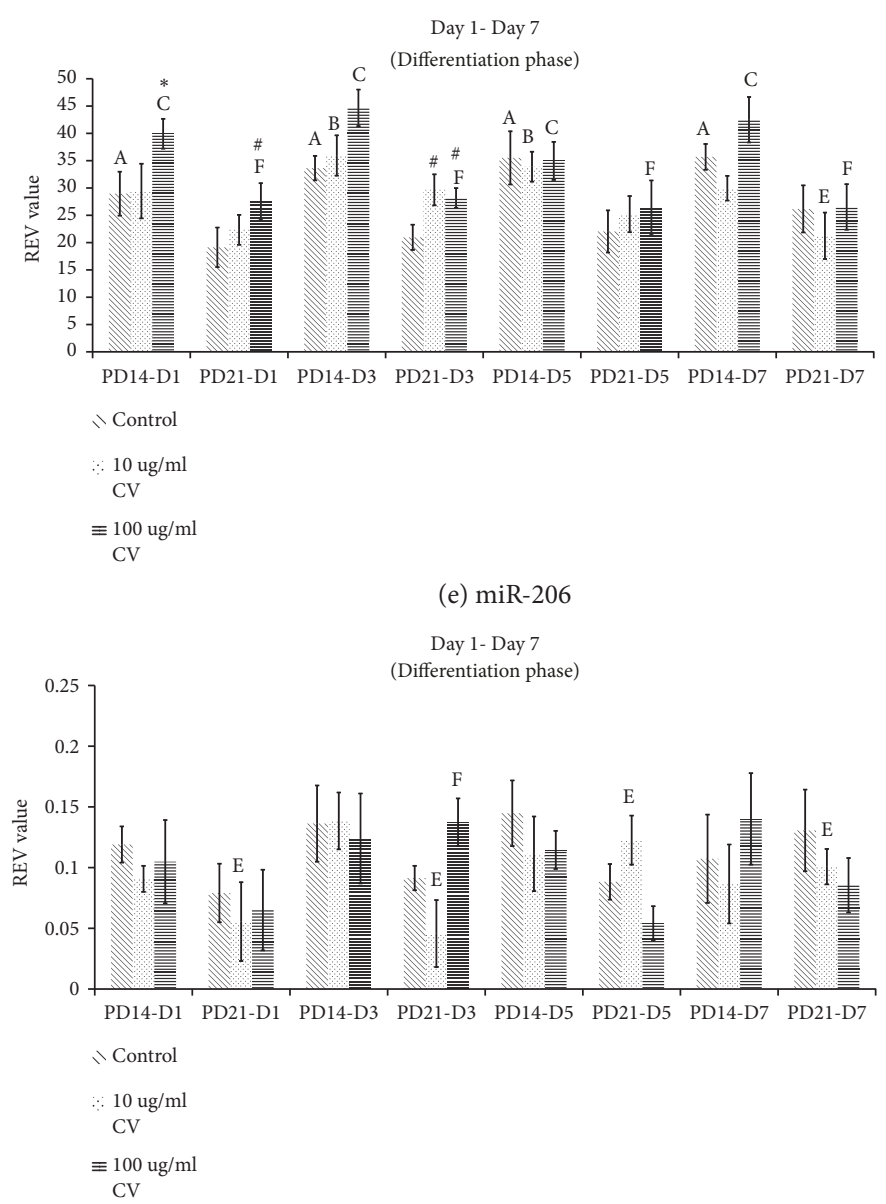

(f) $\operatorname{miR}-486$

Figure 3: Effects of C. vulgaris treatment on the myomiRs expression at Day 0 of differentiation (a-c) and Days 1, 3, 5, and 7 of differentiation (d-f). The expression of myomiRs was determined in control and C. vulgaris-treated young and senescent myoblasts. The data are presented as the means $\pm \mathrm{SD}, \mathrm{n}=3 . * \mathrm{p}<0.05$ significantly different compared to control young on respective day, ${ }^{\#} \mathrm{p}<0.05$ significantly different compared to control senescent on respective day, ${ }^{A} \mathrm{p}<0.05$ significantly different compared to control young on Day $0,{ }^{B} \mathrm{p}<0.05$ significantly different compared to young treated with $10 \mu \mathrm{g} / \mathrm{ml}$ C. vulgaris on Day $0,{ }^{C} \mathrm{p}<0.05$ significantly different compared to young treated with $100 \mu \mathrm{g} / \mathrm{ml}$ C. vulgaris on Day $0,{ }^{D} \mathrm{p}<0.05$ significantly different compared to control senescent on Day $0,{ }^{\mathrm{E}} \mathrm{p}<0.05$ significantly different compared to senescent treated with $10 \mu \mathrm{g} / \mathrm{ml}$ C. vulgaris on Day 0 , and ${ }^{\mathrm{F}} \mathrm{p}<0.05$ significantly different compared to senescent treated with $100 \mu \mathrm{g} / \mathrm{ml} C$. vulgaris on Day 0, with a post hoc Tukey HSD test. 
the $C$. vulgaris-treated senescent myoblast cells demonstrated a significantly increased expression of IGF1R, MEF2C, Myf5, MYOG, Pax7, and PTEN on Day 0 of differentiation as compared to control senescent myoblast cells indicating its role in the regulation of MRFs expression.

Our previous study showed that C. vulgaris improves the regenerative capacity of young and senescent myoblasts and promotes myoblast differentiation. Treatment with C. vulgaris resulted in decreased percentage of senescent myoblast cells stained positive for SA- $\beta$-gal. Additionally, C. vulgaris treatment improved the formation of myotubes in senescent myoblast cells as branched and multinucleated myotubes were observed. Fusion index and maturation index were also significantly higher on Day 5 of differentiation for $C$. vulgaris-treated young myoblast cells and Day 7 of differentiation for $C$. vulgaris-treated senescent myoblast cells as compared to control myoblasts. The percentage of young and senescent myoblast cells positively stained for myogenin was also observed to be significantly increased on Day 3 of differentiation compared to control myoblasts [34]. Thus, the promotion of myogenic differentiation by C. vulgaris was indicated and its potential in promoting muscle regeneration was further proven in the gene expression observed in this study. However, no significant difference was observed on MYH2 gene expression on Day 0 of differentiation in control and C. vulgaris-treated myoblasts for both young and senescent myoblasts. This observation may indicate that this gene is not affected in senescence and its expression is not regulated by C. vulgaris.

Besides MRFs and their regulators, microRNAs have been demonstrated to be involved in myogenic differentiation by modulating the expression of MRFs family in myogenesis. The MRFs, such as MyoD, Myf5, and MYOG, will activate the expression of a collection of myogenic microRNAs. This includes miR-1, miR-133, and miR-206, which are also known as myomiRs $[37,38]$. The findings of this study showed that the expression of miR-133b, miR-206, and miR-486 was significantly decreased in control senescent myoblast cells compared to control young myoblast cells on Day 0 of differentiation indicating the involvement of these microRNAs in cellular senescence of myoblasts. However, a significant increase was observed in C. vulgaris-treated senescent myoblast cells on Day 0 of differentiation which may results in the promotion of myoblasts proliferation. A previous study reported that myoblast extracted from elderly subjects showed downregulation of miR-133b [37].

After limited rounds of proliferation, the majority of satellite cells enter the myogenic differentiation program and begin to fuse with each other to form new myofibers [38]. The paired box 7 ( $P a x 7$ ) is one of the earliest markers during myogenesis. It has been reported that $P a x 7$ regulates muscle marker genes such as $M y f 5$ and $M y o D$ towards differentiation [39]. Proliferating myoblasts continue to express Pax7. However, in contrast to their quiescent progenitors, it also expresses $M y o D$. A reduction in $P a x 7$ along with the induction of muscle-specific transcription factor MYOG marks myoblast that have entered the differentiation phase and initiate cell cycle withdrawal [7]. The Pax7 was also reported to play a dual role in myogenesis regulation by activating commitment to the myogenic program and simultaneously prevent terminal differentiation [40]. Upon commitment to terminal differentiation, upregulation of $M Y O G$ will directly or indirectly downregulate Pax7. A high ratio of Pax7 to $M y o D$ was observed in quiescent satellite cells to maintain satellite cells in their quiescent state. An intermediate ratio of Pax7 and $M y o D$ will allow the satellite cells to proliferate, but not differentiate. However, satellite cells with a low Pax7 to $M y o D$ ratio will begin to differentiate and a further reduction in Pax7 level was observed with activation of MYOG [38]. In this study, a similar finding on $\operatorname{Pax} 7$ and $M y o D$ ratio was observed. The expression of $P a x 7$ was increased in early days of differentiation but later decreased towards the end of differentiation for both young and senescent myoblasts while the expression of $M y O D$ and $M Y O G$ was increased. However, with C. vulgaris treatment, the expression of Pax7 was increased compared to its untreated control on each day of differentiation, in both young and senescent myoblasts indicating the promotion of proliferation and differentiation of myoblast by the alga.

Coinciding with or occurring soon after the upregulation of MYOG, differentiating myoblasts will initiate the expression of various genes encoding for structural proteins, such as sarcomeric myosin which fuse into myotubes [7]. Proliferation of satellite cells leads to the formation of new stem cells, which is maintained in undifferentiated state and myogenic precursor cells that express MRFs for muscle differentiation, which includes $M y o D, M y f 5$, and $M Y O G$. The conversion from quiescent state to the activated state is rapidly followed by muscle differentiation, with myosin heavy chains (MyHCs) expression and myoblast fuse with each other for the formation of myotubes. The activated satellite cells will begin to express either MyoD or Myf5. However, most cells will express both $M y f 5$ and $M y o D$ simultaneously, in which $M Y O G$ will be expressed by the cells followed by the expression of both $M y o D$ and Myf5. Many cells will ultimately express all MRFs simultaneously. The activation of satellite cells followed by proliferation and fusion will occur after one day of injury and up to seven days [41]. In another study, it was described that $M y o D$ and Myf5 were quickly upregulated in young myoblasts during the first hours of differentiation, followed by the expression of cell cycle regulator p57 and MYOG [33]. However, in senescent myoblast, both delay expression and downregulation of $M y o D$ were observed resulting in failure of $M y f 5$ activation. The delayed expression of p57 and MYOG was also observed in senescent myoblast.

The results of our study showed that the expression of $M y o D, M y f 5$, and $M Y O G$ was increased in both young and senescent myoblasts with the increasing number of differentiation days. The expression of these transcription factors was also significantly increased with the treatment of $C$. vulgaris, in both young and senescent myoblasts, thus confirming its potential in promoting myoblast differentiation. A previous study reported that myoblast coexpressing both Myf5 and $M y o D$ exhibits the intermediate growth and differentiation propensities, with the expression of $M y o D$ peaks in mid $\mathrm{G}_{1}$ and Myf5 expression is maximal at the $\mathrm{G}_{0}$ and $\mathrm{G}_{2}$ phases of the cell cycle [38]. 
A previous study reported that serum response factor (SRF) positively regulates the expression of $M y o D$ in proliferating myoblasts by binding to serum response element (SRE) within the $M y o D$ regulatory region. However, SRF only drives low levels of MyoD expression due to its activity which is hindered by cyclin D1 induced dependent kinase 4 (Cdk4). Induction of myocyte enhancer factor-2 (MEF2) expression prior to differentiation enables MEF2 to outcompete SRF for the SRE binding site and consequently resulted in high levels of $M y o D$ expression and initiation of differentiation [38]. The $M E F 2$ family of human transcription factors consists of four proteins, $M E F 2 A, M E F 2 B, M E F 2 C$, and $M E F 2 D$, in which the expression of $M E F 2 C$ was determined in this study. Our finding showed that the expression of $M E F 2 C$ was increased in both young and senescent myoblasts throughout the differentiation day. Treatment with C. vulgaris was found to significantly increase the expression of $M E F 2 C$ as compared to its control on respective day of differentiation. $M E F 2 C$ is involved in the regulation of cytoskeletal structures and loss of $M E F 2 C$ in skeletal muscle will result in improper sarcomere organization. Its isoform, $M E F 2 C \alpha 2$, is predominantly expressed in skeletal muscle and promotes musclespecific gene expression and myogenic differentiation [42, 43]. Thus upregulation of $M E F 2 C$ observed in this study may indicate promotion of myogenic differentiation by C. vulgaris throughout the differentiation day.

Insulin-like growth factors (IGFs) exist as two isoforms, $I G F-I$ and IGF-II that play vital roles in the regulation of satellite cell activity. The IGF exerts pleiotropic functions, such as anti-inflammation, cell migration, and stimulation of both proliferation and differentiation in satellite cells, which is mediated by the binding of IGF-I to IGF-I receptor $(I G F 1 R)$, a ligand-activated receptor tyrosine kinase. The expression level of IGF1R is critical for the regulation of muscle development due to its function in directly regulating the intracellular responsiveness of muscle cell to the extracellular $I G F$ signal. The activation of IGF1R in satellites cells will promote the expression of MRFs, such as MYOG. The IGF1R activates two primary signaling pathways: (1) upon ligand binding, IGF1R becomes auto phosphorylated and induces the phosphatidylinositol 3-kinase (PI3K)/Akt pathway which is involved in myoblast differentiation and (2) IGF1R activates the Ras/Raf/extracellular response kinases (ERKs) cascade, resulting in the activation of other protein kinases and transcription factors for satellite cell proliferation [38, 44]. The results of this study showed that the expression of IGF1R was maintained throughout the differentiation in both young and senescent myoblast cells. However, with $C$. vulgaris treatment, the expression of $I G F 1 R$ was significantly increased in young and senescent myoblasts suggesting promotion of myoblast differentiation by C. vulgaris.

Troponin $\mathrm{T}(\operatorname{Tn} T)$ is a central player in the calcium regulation of actin thin filament function and is essential for the contraction and relaxation of striated muscles. TnT exists as three isoforms, TNNT1 and TNNT3 which are specifically expressed in slow and fast twitch skeletal muscle fibers and TNNT2 which is expressed specifically in cardiac muscle [45]. The deletion of phosphatase and tensin homologue (PTEN) in quiescent satellite cells will cause spontaneous activation of satellite cells and undergo premature differentiation without proliferation, resulting in satellite cells depletion and defective regenerative function of skeletal muscle in response to injury. PTEN is vital for satellite cell homeostasis and the deletion of PTEN in embryonic myogenic progenitors resulted in defective and depleted satellite cells and consequently causes failure to myoblast regeneration $[46,47]$.

The myofibers consist of repeated actin and myosin myofibrils forming sarcomere, which is the basic functional unit of skeletal muscle which is involved in muscle contraction. Skeletal muscle fibers can be categorized into a slow-contracting/fatigue-resistant type and fastcontracting/fatigue-susceptible type muscle fibers. It differs in terms of their myosin heavy chains $(\mathrm{MyHC})$ isoforms and types of metabolism [38]. Various forms of $\mathrm{MyHCs}$ are encoded by a large family of sarcomeric $M Y H$ genes expressed in striated muscles. The $\mathrm{MYH} 2$ gene produces MyHC-2A protein with fast type 2A fibers [48]. In this study, the expression of TNNT, PTEN, and MYH2 was significantly increased in both young and senescent myoblast cells during differentiation. The expressions of TNNT1, PTEN, and MYH2 were significantly increased with $C$. vulgaris treatment indicating its potential in the promotion of muscle differentiation and regeneration.

The microRNAs play an important role during muscle proliferation and differentiation by regulating the expression of a number of transcription factors and signaling molecules required for myogenesis [49]. miR-133b and miR-206 are located at human chromosome $6 \mathrm{p} 12.2$ with tissue specificity towards skeletal muscle, while mir-486 is located at human chromosome 8p11.21 with tissue specificity towards heart and skeletal muscle [16]. The function of each myomiR is summarized as follows: miR-133b promotes myoblasts differentiation and fusion, regeneration, alternative splicing regulation, chromatin remodeling, cell fate regulation, and proapoptotic; miR-206 promotes myoblast differentiation and regeneration, regeneration of neuromuscular synapses, chromatin remodeling, antiangiogenic, proapoptotic, oxidative stress control, and antimigration; and miR-486 promotes myoblast differentiation and fusion, alternative splicing regulation, antiapoptotic, and promigration [50]. Both miR-133b and miR-206 are required for skeletal muscle differentiation.

Generally, the cell signaling pathways targeted by miR206 tend to have opposing functions to the regulatory pathways targeted by miR-133b, in which miR-206 acts to promote myogenic differentiation and miR-133b maintains the undifferentiated state and promotes cell growth; thus coexpression of myomiRs will help in the maintenance of homeostasis under normal cellular conditions. Since the downregulation of myostatin permits expression of miR133b/-206 and MyoD, and MYOG binds to miR-206 promoter, it was suggested that miR-133b/-206 expression in the muscle may also be partly controlled by $M y o D$ and MYOG [51]. In this study, the expression of miR-133b in young myoblasts was significantly increased during differentiation as compared to Day 0. A similar increase in miR-133b was not observed in senescent myoblasts during differentiation suggesting slower regenerative capacity in ageing. Treatment with $C$. vulgaris however was found to increase the expression of miR-133b in 


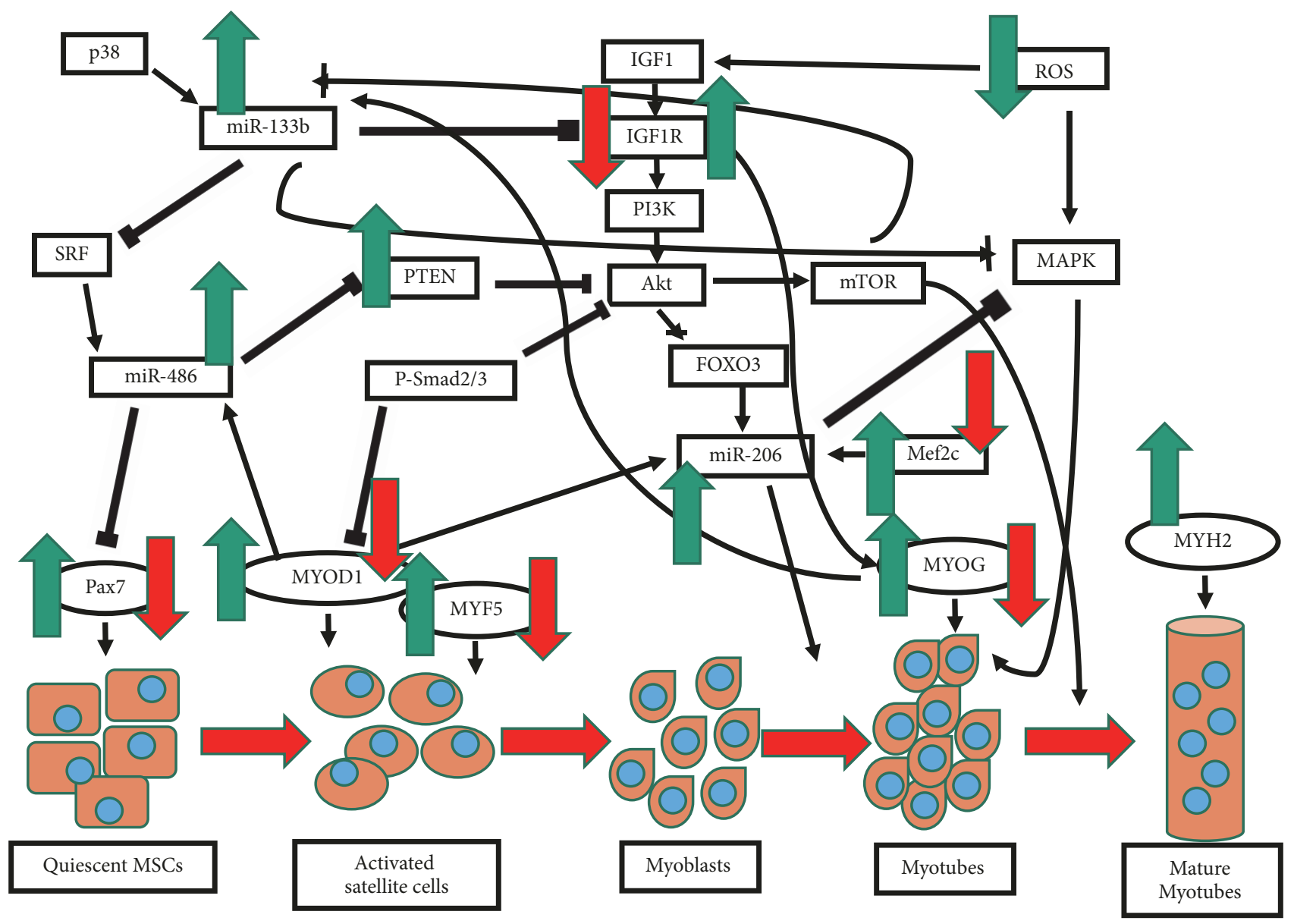

FIGURE 4: The regulation of genes and myomiRs expression in the IGF/PI3K/Akt signaling pathway during myogenesis. Control senescent myoblast cells demonstrated a significantly decreased expression of genes on Day 0 of differentiation, as indicated by red arrow. However, the expression of genes and myomiRs was significantly increased in C. vulgaris-treated young and senescent myoblasts cells throughout the differentiation day, as indicated by green arrows.

senescent myoblasts on Day 3 of differentiation. C. vulgaris treatment also significantly increased the expression of miR206 in young myoblasts on Day 1 and Day 3 of differentiation while the expression of miR-206 in senescent myoblasts was increased only on Day 3 of differentiation. These findings may indicate the potential of C. vulgaris in promoting myogenic differentiation. A previous study reported that increased miR-206 expression in proliferating myoblasts was initiated by the proximal (PROX) promoter. miR-206 is located within the intron of linc-MD1 and is transcribed autonomously under the control of its own PROX promoter [51]. This microRNA is upregulated by $M y o D$ and targets $P a x 3$ and Pax 7 mRNA for myogenic differentiation regulation. Thus, through this miR-206 mediated negative feedback mechanism, MyoD facilitates progression of myoblasts towards terminal differentiation $[52,53]$.

Figure 4 summarizes the myogenesis process which is controlled by a group of myogenic regulatory factors (MRFs) that command the progression from quiescence to activation, proliferation, and differentiation of muscle satellite cells (MSCs). This process will lead to the transformation of individual satellite cell into a syncytial contractile myofibers [38].
Quiescent muscle satellite cells (MSCs) are characterized by the expression of transcription factor Pax7. These MSCs will exit from the quiescent state and will be activated in the presence of stimuli such as damaged to the environment of satellite cells $[38,54]$. The proliferating MSCs will later express MyoD1 and Myf5 for its activation and promotion of entry into the cell cycle, during muscle fiber development and muscle regeneration [54]. It will be further promoted to differentiate by inducing MyoD1 expression. The MYOG expression will initiate terminal differentiation and fusion in immature myotubes and the expression of myosin heavy chain (MYH2) in mature myotubes will activate musclespecific structural and contractile genes, thereby impacting muscle function $[38,54]$. Pax7 will be downregulated upon the activation of myogenic regulatory genes such as $M y f 5$ and MyoD1 during the initiation of myogenesis [55]. Thus, the activated satellite cells will return to quiescence state. This is important to maintain the satellite cell pool for long term muscle integrity [38].

The phosphatidylinositol-3-kinases (PI3K)/Akt signaling pathway is the major signaling pathway which regulates muscle protein synthesis by modulating IGF-1 and insulin 
expression $[4,56]$ that promote protein synthesis and muscle hypertrophy by interacting with their respective tyrosine kinase receptors to phosphorylate the insulin receptor substrate (IRS-1). PI3K/Akt will then activate and stimulate mTOR to further promote protein synthesis [4] (Figure 4). The presence of low levels of reactive oxygen species (ROS) plays an important role in inducing the upregulation of growth factors such as IGF-1 [57].

The IGF-1 targets miR-206 and miR-133 while the PI3K/Akt pathway inhibits FoxO3 expression for the upregulation of miR-206 which resulted in the promotion of myoblast differentiation [50]. The miR-133 has a conserved and functional binding site in the $3^{\prime \prime}$-UTR of IGF-1R, which consequently declined in IGF-1R abundance [14]. The miR-133 will promote myoblast proliferation by targeting the mRNA for serum response factor (SRF) for miR-486 activation [54]. The miR-486 will be highly upregulated during muscle differentiation by targeting $\operatorname{Pax} 7$ and consequently accelerated myoblast differentiation [58]. While the miR-133b will suppress myoblast proliferation and promote myoblast differentiation via mitogen-activated protein kinase (MAPK) regulation, by downregulating its transducers, which includes fibroblast growth factor receptor 1 (FGFR1) and protein phosphatase $2 \mathrm{~A}$ catalytic subunit (PP2AC) [59]. The MAPK is also responsible in ensuring sufficient myoblast accumulation for fusion and myotubes formation. Thus, MAPK negatively regulates miR-133b expression and therefore maintaining proliferation until differentiation induction by a significant upregulation of miR-133b occurs [50].

The expression of myomiRs is dependent on the expression of myogenic regulatory factors such as $M y o D 1, M Y O G$, and $M e f 2 c$ which regulate the balance between myoblast proliferation and differentiation [55]. The $M e f 2 c$ is also responsible for the promotion of miR-206 [50]. The inhibition of Pax7 by miR-486 will result in MyoD1 upregulation and further enhancement of its own expression since miR486 is directly regulated by $M y o D 1$ and SRF [58]. The PTEN is downregulated by miR-486, thereby increasing pAkt, which in turn phosphorylates FoxO resulting in its activation. A previous study reported that muscle wasting is limited by the inactivation of FoxO [14]. The downregulation of miR-486 in normal myoblasts also leads to impaired migration and myoblast fusion [50].

\section{Conclusion}

C. vulgaris may promote myogenic differentiation as indicated by the upregulation of MRFs and myomiRs expression in culture. The modulatory effects of $C$. vulgaris on the expression of MRFs and myomiRs may indicate its potential in promoting muscle regeneration and ameliorating sarcopenia.

\section{Data Availability}

The data used to support the findings of this study are included within the article.

\section{Conflicts of Interest}

The authors declare no conflict of interest.

\section{Funding}

This work was financially supported by the Ministry of Education (MOE) Malaysia [grant number: FRGS/2/2014/ SKK01/UKM/01/1]; and the Universiti Kebangsaan Malaysia [grant number: UKM-FF-2016-318].

\section{Acknowledgments}

The authors are grateful to the University of Malaya Algae Culture Collection (UMACC, Malaysia) for supplying the stock of $C$. vulgaris. We are also thankful for the contribution from all researchers and staffs of Department of Biochemistry and Department of Anatomy, Faculty of Medicine, Universiti Kebangsaan Malaysia Medical Centre.

\section{References}

[1] G. D. Cartee, R. T. Hepple, M. M. Bamman, and J. R. Zierath, "Exercise promotes healthy aging of skeletal muscle," Cell Metabolism, vol. 23, no. 6, pp. 1034-1047, 2016.

[2] I. H. Rosenberg, "Sarcopenia: origins and clinical relevance," Journal of Nutrition, vol. 127, no. 5, pp. 990S-991S, 1997.

[3] M. Muscaritoli, S. D. Anker, J. Argilés et al., "Consensus definition of sarcopenia, cachexia and pre-cachexia: joint document elaborated by Special Interest Groups (SIG) "cachexia-anorexia in chronic wasting disease" and "nutrition in geriatrics"," Clinical Nutrition, vol. 29, no. 2, pp. 154-159, 2010.

[4] M. M. Ziaaldini, E. Marzetti, A. Picca, and Z. Murlasits, "Biochemical pathways of sarcopenia and their modulation by physical exercise: A narrative review," Frontiers in Medicine, vol. 4, no. 167, pp. 1-8, 2017.

[5] W. K. Mitchell, J. Williams, P. Atherton, M. Larvin, J. Lund, and M. Narici, "Sarcopenia, dynapenia, and the impact of advancing age on human skeletal muscle size and strength; a quantitative review," Frontiers in Physiology, vol. 3, article 260, pp. 1-18, 2012.

[6] D. Costamagna, P. Costelli, M. Sampaolesi, and F. Penna, "Role of inflammation in muscle homeostasis and myogenesis," Mediators of Inflammation, vol. 2015, Article ID 805172, 14 pages, 2015.

[7] Z. Yablonka-Reuveni, "The skeletal muscle satellite cell: still young and fascinating at 50," Journal of Histochemistry \& Cytochemistry, vol. 59, no. 12, pp. 1041-1059, 2011.

[8] J. M. Hernández-Hernández, E. G. García-González, C. E. Brun, and M. A. Rudnicki, "The myogenic regulatory factors, determinants of muscle development, cell identity and regeneration," Seminars in Cell \& Developmental Biology, vol. 72, pp. 10-18, 2017.

[9] M. Buckingham and P. Rigby, "Gene regulatory networks and transcriptional mechanisms that control myogenesis," Developmental Cell, vol. 28, no. 3, pp. 225-238, 2014.

[10] M. Li and J. C. I. Belmonte, "Genetic rejuvenation of old muscle," Nature, vol. 506, article 7488, pp. 304-305, 2014.

[11] P. Sousa-Victor, S. Gutarra, L. García-Prat et al., "Geriatric muscle stem cells switch reversible quiescence into senescence," Nature, vol. 506, pp. 1-16, 2014. 
[12] E. Bengal, E. Perdiguero, A. L. Serrano, and P. Muñoz-Cánoves, "Rejuvenating stem cells to restore muscle regeneration in aging," F1000Research, vol. 6, pp. 1-10, 2017.

[13] K. Felekkis, C. T. E. Stefanou, and C. Deltas, "Micrornas: anewly described class of encoded molecules that play a role in health and disease," Hippokratia, vol. 14, no. 4, pp. 236-240, 2010.

[14] X. H. Wang, "MicroRNA in myogenesis and muscle atrophy," Current Opinion in Clinical Nutrition \& Metabolic Care, vol. 16, no. 3, pp. 258-266, 2013.

[15] M. Ha and V. N. Kim, "Regulation of microRNA biogenesis," Nature Reviews Molecular Cell Biology, vol. 15, pp. 509-524, 2014.

[16] J. Siracusa, N. Koulmann, and S. Banzet, "Circulating myomiRs: a new class of biomarkers to monitor skeletal muscle in physiology and medicine," Journal of Cachexia, Sarcopenia and Muscle, vol. 9, no. 1, pp. 20-27, 2018.

[17] H. S. Lee, H. J. Park, and M. K. Kim, "Effect of Chlorella vulgaris on lipid metabolism in Wistar rats fed high fat diet," Nutrition Research and Practice, vol. 2, no. 4, pp. 204-210, 2008.

[18] G. P. Diniz and D. Z. Wang, "Regulation of skeletal muscle by micrornas," Comprehensive Physiology, vol. 6, no. 3, pp. 12791294, 2011.

[19] WHO, World Report on Ageing And Health, World Health Organization, 2015.

[20] P. Spolaore, C. Joannis-Cassan, E. Duran, and A. Isambert, "Commercial applications of microalgae," Journal of Bioscience and Bioengineering, vol. 101, no. 2, pp. 87-96, 2006.

[21] S. S. Ahluwalia and D. Goyal, "Microbial and plant derived biomass for removal of heavy metals from wastewater," Bioresource Technology, vol. 98, no. 12, pp. 2243-2257, 2007.

[22] C. F. Gao, Y. Zhai, Y. Ding, and Q. Wu, "Application of sweet sorghum for biodiesel production by heterotrophic microalga Chlorella protothecoides," Applied Energy, vol. 87, no. 3, pp. 756761, 2010.

[23] L. Krienitz, V. A. Huss, and C. Bock, "Chlorella: 125 years of the green survivalist,” Trends in Plant Science, vol. 20, no. 2, pp. 6769, 2015.

[24] C. Safi, B. Zebib, O. Merah, P. Pontalier, and C. Vaca-Garcia, "Morphology, composition, production, processing and applications of Chlorella vulgaris: A review," Renewable \& Sustainable Energy Reviews, vol. 35, pp. 265-278, 2014.

[25] H. Jeong, H. J. Kwon, and M. K. Kim, "Hypoglycemic effect of Chlorella vulgaris intake in type 2 diabetic Goto-Kakizaki and normal Wistar rats," Nutrition Research and Practice, vol. 3, no. 1, pp. 23-30, 2009.

[26] O. Aizzat, S. Yap, H. Sopiah et al., "Modulation of oxidative stress by Chlorella vulgaris in streptozotocin (STZ) induced diabetic Sprague-Dawley rats," Advances in Medical Sciences, vol. 55, no. 2, pp. 281-288, 2010.

[27] W. Z. W. Ngah and Y. A. M. Yusof, "Chemopreventive effect of chlorella vulgaris in choline deficient diet and ethionine induced liver carcinogenesis in rats," International Journal of Cancer Research, vol. 2, no. 3, pp. 234-241, 2006.

[28] E. S. M. Azamai, S. Sulaiman, S. H. M. Habib et al., "Chlorella vulgaris triggers apoptosis in hepatocarcinogenesis-induced rats," Journal of Zhejiang University SCIENCE B, vol. 10, no. 1, pp. 14-21, 2009.

[29] N. A. Mukti, S. Sulaiman, S. M. Saad, and H. Basari, "Chlorella vulgaris menunjukkankesanantioksidandan antitumor terhadapkanserhepardalamkajian in vivo dan in vitro," SainsMalaysiana, vol. 38, no. 3, pp. 773-784, 2009.
[30] S. M. Saad, Y. A. M. Yusof, and W. Z. W. Ngah, "Comparison between locally produced Chlorella vulgaris and Chlorella vulgaris from Japan on proliferation and apoptosis of liver cancer cell line, HepG2," Malaysian Journal of Biochemistry and Molecular Biology, vol. 13, no. 1, pp. 32-36, 2006.

[31] K. Kitada, S. Machmudah, M. Sasaki et al., "Supercritical CO2 extraction of pigment components with pharmaceutical importance from Chlorella vulgaris," Journal of Chemical Technology and Biotechnology, vol. 84, no. 5, pp. 657-661, 2009.

[32] Y. Panahi, B. Pishgoo, H. R. Jalalian et al., "Investigation of the effects of Chlorella vulgaris as an adjunctive therapy for dyslipidemia: Results of a randomised open-label clinical trial," Nutrition \& Dietetics, vol. 69, no. 1, pp. 13-19, 2012.

[33] A. Bigot, V. Jacquemin, F. Debacq-Chainiaux et al., "Replicative aging down-regulates the myogenic regulatory factors in human myoblasts," Biology of the Cell, vol. 100, no. 3, pp. 189199, 2008.

[34] N. Z. Azlan, Y. A. M. Yusof, E. Alias, and S. Makpol, “Chlorella vulgaris improves the regenerative capacity of young and senescent myoblasts and promotes muscle regeneration," Oxidative Medicine and Cellular Longevity, vol. 2019, Article ID 3520789, 16 pages, 2019.

[35] T. D. Schmittgen and K. J. Livak, "Analyzing real-time PCR data by the comparative CT method," Nature Protocols, vol. 3, no. 6, pp. 1101-1108, 2008.

[36] S. E. Alway, M. J. Myers, and J. S. Mohamed, "Regulation of satellite cell function in sarcopenia," Frontiers in Aging Neuroscience, vol. 6, article 246, pp. 1-15, 2014.

[37] E. S. Di Filippo, R. Mancinelli, T. Pietrangelo et al., "Myomir dysregulation and reactive oxygen species in aged human satellite cells," Biochemical and Biophysical Research Communications, vol. 473, no. 2, pp. 462-470, 2016.

[38] H. Yin, F. Price, and M. A. Rudnicki, "Satellite cells and the muscle stem cell niche," Physiological Reviews, vol. 93, no. 1, pp. 23-67, 2013.

[39] W. Izumi, Y. Takuma, R. Ebihara, W. Mizunoya, R. Tatsumi, and M. Nakamura, "Paired box 7 inhibits differentiation in 3T3-L1 preadipocytes," Animal Science Journal, vol. 89, no. 8, pp. 12141219, 2018.

[40] H. C. Olguín and A. Pisconti, "Marking the tempo for myogenesis: Pax7 and the regulation of muscle stem cell fate decisions," Journal of Cellular and Molecular Medicine, vol. 16, no. 5, pp. 1013-1025, 2012.

[41] S. Ciciliot and S. Schiaffino, "Regeneration of mammalian skeletal muscle. Basic mechanisms and clinical implications," Current Pharmaceutical Design, vol. 16, no. 8, pp. 906-914, 2010.

[42] M. J. Potthoff, M. A. Arnold, J. McAnally, J. A. Richardson, R. Bassel-Duby, and E. N. Olson, "Regulation of skeletal muscle sarcomere integrity and postnatal muscle function by Mef2c," Molecular and Cellular Biology, vol. 27, no. 23, pp. 8143-8151, 2007.

[43] J. R. Pon and M. A. Marra, "MEF2 transcription factors: developmental regulators and emerging cancer genes," Oncotarget, vol. 7, no. 3, pp. 2297-2312, 2016.

[44] M.-B. Huang, H. Xu, S.-J. Xie, H. Zhou, and L.-H. Qu, "Insulinlike growth factor-1 receptor is regulated by microRNA-133 during skeletal myogenesis," PLoS ONE, vol. 6, no. 12, Article ID e29173, 2011.

[45] B. Wei and J.-P. Jin, "TNNT1, TNNT2, and TNNT3: Isoform genes, regulation, and structure-function relationships," Gene, vol. 582, no. 1, pp. 1-13, 2016. 
[46] F. Yue, P. Bi, C. Wang, J. Li, X. Liu, and S. Kuang, "Conditional loss of Pten in myogenic progenitors leads to postnatal skeletal muscle hypertrophy but age-dependent exhaustion of satellite cells," Cell Reports, vol. 17, no. 9, pp. 2340-2353, 2016.

[47] F. Yue, P. Bi, C. Wang et al., "Pten is necessary for the quiescence and maintenance of adult muscle stem cells," Nature Communications, vol. 8, no. 1, pp. 1-13, 2017.

[48] S. Schiaffino, "Muscle fiber type diversity revealed by antimyosin heavy chain antibodies," FEBS Journal, vol. 285, no. 20, pp. 3688-3694, 2018.

[49] T. Sadkowski, A. Ciecierska, J. Oprządek, and E. Balcerek, "Breed-dependent microRNA expression in the primary culture of skeletal muscle cells subjected to myogenic differentiation," BMC Genomics, vol. 19, no. 109, pp. 1-14, 2018.

[50] M. Horak, J. Novak, and J. Bienertova-Vasku, "Muscle-specific microRNAs in skeletal muscle development," Developmental Biology, vol. 410, no. 1, pp. 1-13, 2016.

[51] K. R. Mitchelson and W.-Y. Qin, "Roles of the canonical myomiRs miR-1, -133 and -206 in cell development and disease," World Journal of Biological Chemistry, vol. 6, no. 3, p. 162, 2015.

[52] J.-F. Chen, Y. Tao, J. Li et al., "microRNA-1 and microRNA206 regulate skeletal muscle satellite cell proliferation and differentiation by repressing Pax7," The Journal of Cell Biology, vol. 190, no. 5, pp. 867-879, 2010.

[53] H. Hirai, M. Verma, S. Watanabe, C. Tastad, Y. Asakura, and A. Asakura, "MyoD regulates apoptosis of myoblasts through microRNA-mediated down-regulation of Pax3," The Journal of Cell Biology, vol. 191, no. 2, pp. 347-365, 2010.

[54] D. Salvatore, W. S. Simonides, M. Dentice, A. M. Zavacki, and P. R. Larsen, "Thyroid hormones and skeletal muscle New insights and potential implications," Nature Reviews Endocrinology, vol. 10, no. 4, pp. 206-214, 2014.

[55] C. G. Crist and M. Buckingham, "microRNAs gain magnitude in muscle," Cell Cycle, vol. 8, no. 22, pp. 3627-3628, 2014.

[56] S. K. Powers, A. B. Morton, B. Ahn, and A. J. Smuder, "Redox control of skeletal muscle atrophy," Free Radical Biology \& Medicine, vol. 98, pp. 208-217, 2016.

[57] E. Barbieri and P. Sestili, "Reactive oxygen species in skeletal muscle signaling," Journal of Signal Transduction, vol. 2012, Article ID 982794, 17 pages, 2012.

[58] B. K. Dey, J. Gagan, and A. Dutta, "miR-206 and -486 induce myoblast differentiation by downregulating Pax7," Molecular and Cellular Biology, vol. 31, no. 1, pp. 203-214, 2011.

[59] Y. Feng, L. Niu, W. Wei et al., "A feedback circuit between miR133 and the ERK1/2 pathway involving an exquisite mechanism for regulating myoblast proliferation and differentiation," Cell Death \& Disease, vol. 4, no. 11, p. e934, 2013. 


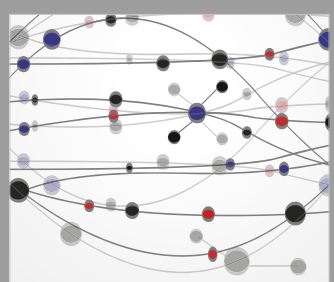

The Scientific World Journal
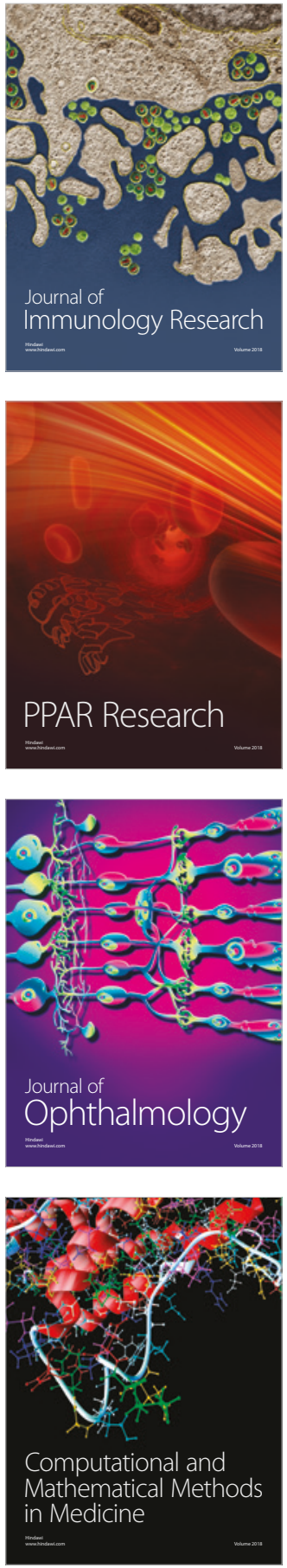

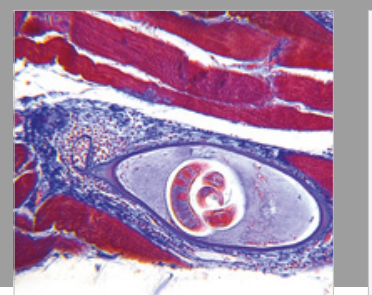

Gastroenterology Research and Practice

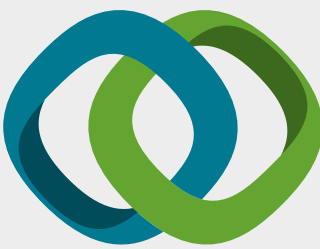

\section{Hindawi}

Submit your manuscripts at

www.hindawi.com
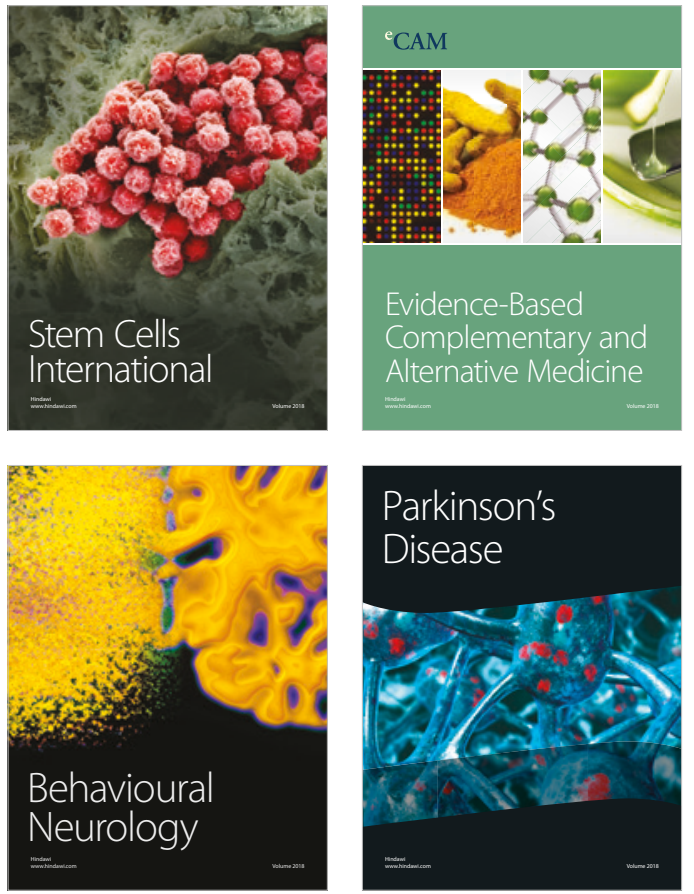

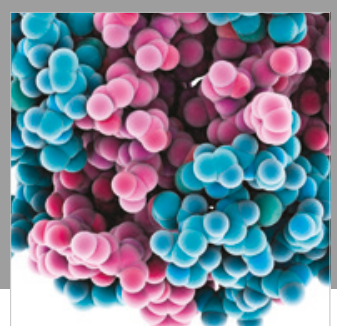

ournal of

Diabetes Research

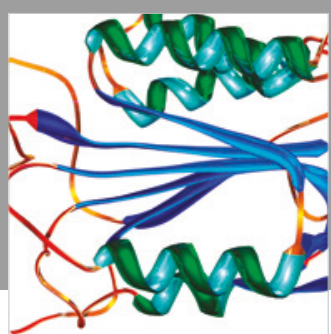

Disease Markers
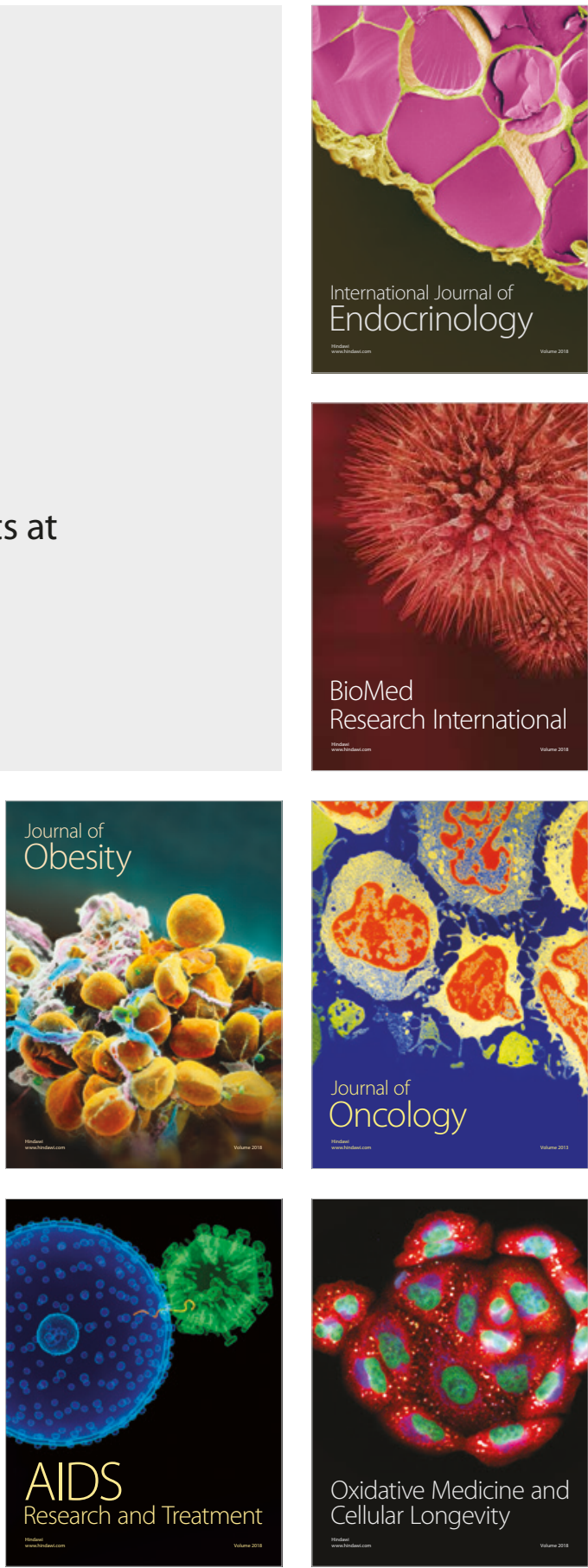